\section{No ARS BILDUMA ISSN 1989-9262 UPV/EHU Press} ARSBILDUMA (CC BY-NC-ND 4.0)

https://doi.org/10.1387/ars-bilduma.20939 BIBLID [(2020), 10; 49-68]

Recibido: 19/06/2019 Aceptado: 25/11/2019

\title{
CONTRIBUCIÓN AL CATÁLOGO DEL ESCULTOR FELIPE DE ESPINABETE (1719-1799)
}

\section{CONTRIBUTION TO THE CATALOGUE OF THE SCULPTOR FELIPE DE ESPINABETE}

(1719-1799)

\section{CONTRIBUTION AU CATALOGUE DU SCULPTEUR FELIPE DE ESPINABETE (1719-1799)}

\section{RESUMEN}

Con motivo del Tercer Centenario del nacimiento del escultor Felipe de Espinabete (1719-1799), uno de los más conspicuos maestros del Rococó castellano el presente artículo quiere dar a conocer una serie de nuevas atribuciones que aumentan sensiblemente su catálogo productivo.

\section{PALABRAS CLAVE}

Escultura barroca y rococó; Siglo XVIII Felipe de Espinabete; Valladolid.

\section{ABSTRACT}

On the occasion of the Third Centenary of the birth of the sculptor Felipe de Espinabete (1719-1799), one of the most conspicuous masters of the Castilian Rococo, this article wants to present series of new attributions that significantly increase its productive catalogue.

KEYWORDS

Baroque and Rococo sculpture; 18th century; Felipe de Espinabete; Valladolid.

\section{RÉSUMÉ}

A l'occasion du Troisiéme Centenaire de la naissance du sculpteur Felipe de Espinabete (1719-1799), l'un des maîtres les plus remarquables du rococo castillian, cet article veut présenter una série de nouvelles attributions qui augmentent considérablement son catalogue productif.

\section{MOTS-CLÉS}

Sculpture Baroque et Rococo; XVIIIe siècle; Felipe de Espinabete; Valladolid. 


\section{INTRODUCCIÓN}

En el año 2019 se ha cumplido el III centenario del nacimiento del escultor Felipe de Espinabete (1719-1799) ${ }^{1}$, el último gran escultor del Barroco vallisoletano y uno de los maestros más conspicuos del Rococó castellano. La celebración de tal efeméride ha pasado completamente desapercibida y ello a pesar de que estamos hablando del último gran maestro del ilustre foco escultórico vallisoletano.

Nacido en Tordesillas el 1 de mayo del año $1719^{2}$, debió de formarse como escultor en Valladolid al lado de Pedro de Ávila (1678-1755) si bien le influyó sobremanera el estilo de Pedro de Sierra (1702-1760/1761), así como las iconografías desarrolladas por éste ${ }^{3}$. Una

1 Felipe de Espinabete ha sido uno de los escultores barrocos del foco castellano que más interés ha suscitado para los investigadores, especialmente en las últimas décadas: MARTÍ Y MONSÓ, J.: Estudio histórico-artísticos relativos principalmente a Valladolid: basados en la investigación de diversos archivos. histórico-artísticos relativos principalmente a Valladolid: basados en la investigación de diversos archivos. dolid. I, Escultura. Valladolid, 1930, pp. 119-120; GARCÍA CHICO, E.: Documentos para el estudio de arte en Castilla. 2, Escultores. Valladolid, 1941, p. 438; MARTÍN GONZALEZ, J. J.: "Cabezas de santo degollados en la escultura barroca española”, Goya: revista de arte, № 16, 1957, pp. 210-213; MARTíN GONZÁLEZ, J. J.: Escultura barroca castellana. Madrid, 1959, pp. 350-355; CAAMAÑO MARTÍNEZ M. "Datos para la historia de lo Real Academin de la Puríima Concepción, de Valladolid (1786-1797)", M.. “Datos para la histo de lo Rel Acce GONZÁLEZ, J.J.: Escultura barroca castellana. Segunda parte. Madrid, 1971, p. 108; YARZA LUACES, J.: "Un San Juan Bautista degollado de Felipe de Espinabete en Santibáñez del Val (Burgos)", B.S.A.A № 38, 1972, pp. 560-562; BRASAS EGIDO, J. C. y NIETO GONZÁLEZ, J. R.: "Felipe de Espinabete nuevas obras", B.S.A.A., № 43, 1977, pp. 479-484; BRASAS EGIDO, J. C.: "Noticias sobre Espinabete", B.S.A.A., No 45, 1979, pp. 495-498; URREA, J.: "Nuevos datos y obras del escultor Felipe de Espinabete", B.S.A.A., No 51, 1985, pp. 507-510; MARTÍN GONZÁLEZ, J. J.: Escultura barroca en España, 16001770 Madrid, 1991, pp. 453-455. VÁZQUEZ GARCÍA, F. "Varias esculturas de Felipe de Espinabete " glesias but

delcoro alto del monsterio de sa URREA, J.: "El escultor Felipe de Espinabete (1719-1799)". En REDONDO, J.; BAZÁN, P.; GARCÍA, A. M.: Tordesillas a través de su Semana Santa. Valladolid, 2000, pp. 119-122; FRUTOS SASTRE, L. M. "Dos nuevos pasos procesionales de Felipe de Espinabete en la provincia de Segovia". Boletín de la Real Academia de Bellas Artes de la Purísima Concepción (en adelante B.R.A.C.), № 37, 2002, pp. 107-112 ALBARRÁN MARTÍN, V.: "Un San Francisco del escultor Felipe de Espinabete (1719-1799)", B.R.A.C. No 45, 2010, pp. 65-68; VÁZQUEZ GARCÍA, F.: "Esculturas de Felipe de Espinabete en San Martín de Arévalo" Cuadernos de Cultura y Patrimonio La Alhóndiga Asociación de Cultura y Patrimonio, No 22 A sobre su posible formación", BSAA Arte, № 82, 2016, pp. 205-227.

URREA, J.: "Nuevos datos...", op. cit., p. 508.

BALADRÓN ALONSO, J.: "El escultor...", op. cit., pp. 206-208. vez completada su formación, contraído matrimonio y tras varios viajes de ida y vuelta entre Tordesillas y Valladolid parece ser que se asentó definitivamente en la ciudad del Pisuerga hacia los años 1747-1750, convirtiéndose pronto en uno de los maestros más cotizados de la urbe ${ }^{4}$. El reconocimiento a su exitosa carrera le llegó el 14 de diciembre de 1784 cuando la Real Academia de Bellas Artes de la Purísima Concepción le nombró académico. Espinabete quedó tan agradecido por su recepción que ofreció a la corporación treinta dibujos de su mano "para que sirviesen de modelo a los discípulos de la Institución"5. Su vida se apagó el 29 de agosto de 1799 en casa de su hijo Blas y su cuerpo fue sepultado en la primitiva iglesia de San Juan Bautista ${ }^{6}$. Sentenciaba Urrea, y con toda la razón, que con su desaparición se ponía punto y final a "la escuela de los grandes maestros de la escultura barroca castellana de la que, sin duda, Espinabete fue digno epílogo y el último representante de calidad"7.

\subsection{La obra de Felipe de Espinabete}

Felipe de Espinabete fue un maestro bastante versátil tal y como parece indicarlo su amplio y variado catálogo productivo, en el que tienen cabida diferentes materiales (madera, piedra y barro) y temáticas (religiosa y profana, véase en este caso las estatuas de Alfonso III y Alfonso VI ${ }^{8}$. Su obra puede agruparse en cuatro grandes bloques, si bien algunas esculturas escapan a tal clasificación: imágenes para retablos, relieves para sillerías, "pasos" procesionales y cabezas de santos decapitados, siendo esta última temática en la que verdaderamente se especializó y le hizo ganar merecida fama.

4 Tal es así que en el Catastro del Marqués de la Ensenada realizado en 1752 se le valuaban unos ingreso diarios de 10 reales la misma cantidad que se le estimaba a Fernando González José Fernández y Pedro de Sierra, el artista más prestigioso con el que contaba Valladolid en aquella época. MARTíN GONZÁLEZ, J. J.: Escultura barroca castellana, op. cit., p. 48.

AGAPITO Y REVILLA, J.: op. cit., p. 120; BRASAS EGIDO, J. C.: "Noticias...", op. cit., p. 496. Con e paso de los años llegó a desempeñar el cargo de Teniente de Dibujo. CAAMAÑO MARTíNEZ, J.M. op. cit., p. 106.

6 URREA, J.: "Nuevos datos...", op. cit., p. 508

URREA, J.: "El escultor...", op. cit., p. 122.

8 CAMPOS SÁNCHEZ-BORDONA, M. D. "La reforma del monasterio de San Benito en la Edad Moderna". En HERRÁEZ ORTEGA, M. V. [et al.]: Esplendor y decadencia de un monasterio medieval: el patrimonio artístico de San Benito de Sahagún, León, 2000, p. 221. Es probable que las efigies de ambos reyes sean las conservadas en el Arco de San Benito de la citada población leonesa. BALADRÓN ALONSO, J.: "El escultor...", op. cit., pp. 206-208 
Las primeras esculturas para retablos que le tenemos documentadas son las que realizó en 1753 para el mayor de la iglesia de San Martín de Arévalo (San Martín partiendo la capa con el pobre, San Isidro y Santa María de la Cabeza) ${ }^{9}$, a las que siguieron las de la Virgen del Carmen y el San Miguel Arcángel (1778-1779) de Solana de Rioalmar (Ávila) ${ }^{10}$ y las de San Francisco y San Luis (1787) del Convento de San Francisco de Tordesillas (Valladolid $)^{11}$. De cronología incierta es el San Miguel Arcángel que, enajenado a mediados del siglo pasado, talló para la iglesia de San Nicolás de Valladolid ${ }^{12}$. Atribuidas, aunque con esa misma función retablística, tenemos el San Antonio Abad (ca. 1761-1762) del Monasterio de Santa María de Valbuena (Valladolid) ${ }^{13}$, las efigies de San Francisco orando ante el Crucifijo y Cristo Yacente (ca. 1773) que talló para sendos retablos de la iglesia de San Andrés de Valladolid ${ }^{14}$, las de Cristo Crucificado y San José (ca. 1782) de San Román de Hornija (Valladolid) ${ }^{15}$, el San Benito (ca. 1782) conservado en San Pedro de Frómista (Palencia) ${ }^{16}$, el Cristo Crucificado (1782) de Villanueva de los Caballeros (Valladolid) ${ }^{17}$. Además, un amplio conjunto de imágenes (ca. 1775-1777), la mayoría pertenecientes a retablos, han sido relacionadas con el escultor y su taller en el Monasterio de Santa María Magdalena de Medina del Campo (Valladolid) ${ }^{18}$

VÁZQUEZ GARCÍA, F.: op. cit., pp. 445-448

10 Ídem, pp. 448-450.

11 ALBARRÁN MARTÍN, V: op. cit p. 65. Estas imágenes, de las que tan solo se conserva la de San Francisco en el Museo de San Antolín, vendrían a sustituir a otras dos de las mismas advocaciones que el propio Espinabete restauró en 1756. ARA GIL, C. J. y PARRADO DEL OLMO, J. M.: Catálogo Monumenta de la provincia de Valladolid. Tomo XI. Antiguo partido judicial de Tordesillas. Valladolid, 1980, p. 298.

12 URREA, J.: "Nuevos datos..., op. cit., p. 511.

13 Ibídem.

14 MARTÍN GONZÁLEZ, J. J. y URREA FERNÁNDEZ, J.: Catálogo Monumental de la provincia de Valladolid. Tomo XIV. Monumentos religiosos de la ciudad de Valladolid (1 ${ }^{a}$ parte). Valladolid, 1985, p. 54 BALADRÓN ALONSO, J.: "El escultor..., op. cit., p. 219.

15 Ídem, pp. 221-222.

16 Ídem, pp. 224-225.

17 Ídem, pp. 222-223

18 En el retablo de la Inmaculada Concepción se encuentran las de la Inmaculada, San Nicolás de Tolentino, San Guillermo de Aquitania y Santa Clara de Montefalco; en el retablo de Santa Rita de Casia las de la titular, Santa Juliana del Busto y Santa Catalina de Palacia; en el retablo de San Agustín la de titular, Santo Tomás de Villanueva y San Juan de Sahagún. No pertenecientes a retablos, pero también atribuidas a Espinabete $y$ a su taller, tenemos otras conservados en la clausura: San Luis Gonzaga, San

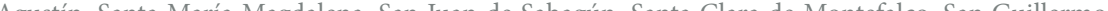
Santo Tomás de Villa Magdá DEL BARRIO, A.: Clausuras: el patrimonio de los conventos de la provincia de Valladolid. 1, Medina del Campo. Valladolid, 1999, pp. 75, 152-153, 157, 159, 162 y 170
Su verdadera especialidad fue la escultura de pequeño formato -fundamentalmente las cabezas de santos decapitados-, en la que destaca sobremanera la hermosísima Magdalena en el desierto del Museo Nacional de Escultura ${ }^{19}$. El ejemplar más temprano que le conocemos es la Cabeza de San Pablo (1760) que talló para el Monasterio de Nuestra Señora de Prado ${ }^{20}$ y en la cual copió sin concesiones la ejecutada años atrás por Villabrille y Ron para el Convento de San Pablo. A esta siguieron las Cabezas San Juan Bautista de la iglesia de San Andrés de Valladolid $(1773)^{21}$, de Santibáñez del Val (Burgos) (1774)22, y del Monasterio de La Santa Espina (Valladolid) (1779) ${ }^{23}$, y las parejas de Cabezas de San Juan Bautista y San Pablo del Convento de las Mercedarias Descalzas de Toro (Zamora) (1778) ${ }^{24}$, y de Las Lauras de Valladolid $(1778)^{25}$. A estas testas sacras documentadas han de añadirse otros cuatro ejemplares de la Cabeza de San Pablo que se le atribuyen en el Museo de San Francisco de Medina de Rioseco (Valladolid) ${ }^{26}$, en la iglesia del Salvador de Tiedra (Valladolid) ${ }^{27}$, en Fuente de Santa Cruz (Segovia) ${ }^{28}$, y en el Monasterio de Santo Domingo el antiguo de Toledo ${ }^{29}$, contando las dos primeras con la particularidad de estar modeladas en barro cocido.

También destacó Espinabete en la elaboración de sillerías de coro. Así, en 1766 contrató a del Monasterio de La Santa Espina (Valladolid) (actualmente en la iglesia de San Juan Bautista de la localidad zamorana de Villavendimio) ${ }^{30}$, y hacia 1773 tenía acabadas dieciséis

19 WATTENBERG, F. Guía del Museo Nacional de Escultura de Valladolid Madrid, 1966, p. 73.

20 MARTÍ Y MONSÓ, J.: op. cit., p. 643.

21 AGAPITO Y REVILLA, J.: op. cit., p. 120

22 YARZA LUACES, J.: op. cit., pp. 560-562.

23 BRASAS EGIDO, J. C.: “Noticias...", op. cit., pp. 495-498

24 NAVARRO TALEGÓN, J.: I centenario de la fundación de la Orden Mercedaria descalza de Toro (18861986). Zamora, 1986, pp. 25-26.

25 Tras el cierre del cenobio vallisoletano a mediados de la década de 1990 la Cabeza de San Pablo marchó al Convento de San Pedro Mártir de Mayorga de Campos (Valladolid) y la de San Juan Bautista al de Sancti Spiritus de la localidad zamorana de Toro. AGAPITO Y REVILLA, J.: op. cit., p. 119; MARTÍN GONZÁLEZ, J. J. y DE LA PLAZA SANTIAGO, F. J.: Catálogo Monumental de la provincia de Valladolid. Tomo XV. Monumentos religiosos de la ciudad de Valladolid (2a parte). Valladolid, 2001, p. 160; ARIAS MARTÍNEZ M., HERNÁNDEZ REDONDO, J. I. y SÁNCHEZ DEL BARRIO, A.: Clausuras: el patrimonio de los conventos de la provincia de Valladolid. 3, Medina de Rioseco - Mayorga de Campos - Tordesillas - Fuensalda ña y Villafrechós. Valladolid, 2004, pp. 46 y 187; BALADRÓN ALONSO, J.: “El escultor...”, op. cit., p. 211.

26 URREA, J. (coord.). El Museo de Santa María de Medina de Rioseco. Valladolid, Caja de Ahorros Popular de Valladolid, 1987, pp. 48-49.

27 MARTÍN GONZÁLEZ, J. J.: "Cabezas de santos..." op. cit., p. 213

28 MARTÍN GONZÁLEZ, J. J.: Escultura barroca castellana. Segunda..., op. cit., p. 108

29 VÁZQUEZ GARCÍA, F.: "Esculturas de Felipe de Espinabete..., op. cit., s/p.

30 BRASAS EGIDO, J. C. y NIETO GONZÁLEZ, J. R.: op. cit., pp. 479-484. 
sillas de coro para el Monasterio de los Santos Mártires de Valladolid ${ }^{31}$. Será también suya la magnífica sillería de legos del Monasterio de San Benito el Real de Valladolid (1764), cuyas sillas altas se conservan en el Museo Diocesano de Valladolid y las bajas en el Museo Nacional de Escultura ${ }^{32}$

En cuanto a escultura procesional, para la Cofradía de la Vera Cruz de Tordesillas ejecutó los pasos del Azotamiento (1766) y de Jesús Nazareno $(1768)^{33}$, atribuyéndosele también en esta localidad un Cristo del Perdón $n^{34}$ que copia el famoso modelo creado por Manuel Pereira. Para Toro (Zamora) talló una Virgen de la Soledad que pereció en 1957 víctima de un incendio ${ }^{35}$. Ya en sus últimos años realizó el Cristo atado a la columna y el Ecce Homo (1792) del Monasterio de Nuestra Señora de la Soterraña en Santa María la Real de Nieva (Segovia) ${ }^{36}$. Asimismo, también le pertenecerá un magnífico Cristo atado a la columna (ca. 1774-1777) ${ }^{37}$ conservado en la parroquial de La Seca (Valladolid) y que viene a ser una réplica de sus dos ejemplares documentados.

Finalmente existe otra serie de obras atribuidas que vienen a completar un extenso catálogo. Así, en Valladolid capital podemos reseñar el San Juan Nepomuceno de la iglesia de la Magdalena ${ }^{38}$, el San Gregorio Magno del Monasterio de San Benito el Real ${ }^{39}$, dos santos benedictinos -probablemente pertenecientes al mismo conjunto del San Gregorio Magno- en la iglesia de San Miguel ${ }^{40}$, la efigie del Santísimo Salvador que preside la sacristía de la iglesia homónima ${ }^{41}$, o un Busto de Ecce Homo conservado en la iglesia de Santiago Apóstol $^{42}$. Un desaparecido San Juan Bautista en el desierto ${ }^{43}$ existió en el Monasterio de

31 REDONDO CANTERA, M. J.: "Los inventarios de obras de arte de los conventos vallisoletanos durante la Guerra de la Independencia”, B.S.A.A., № 58, 1992, p. 503

32 FERNÁNDEZ GONZÁLEZ, M. R.: op. cit., pp. 499-514

33 URREA FERNÁNDEZ, J.: Cuadernos vallisoletanos No 24: Semana Santa. Valladolid, 1987, p. 23

34 Ídem, p. 22.

5 NAVARRO TALEGÓN, J.: Catálogo monumental de Toro y su Alfoz. Zamora, 1980, p. 163.

36 FRUTOS SASTRE, L. M.: op. cit., pp. 107-112.

37 BALADRÓN ALONSO, J.: “El escultor...”, op. cit., pp. 220-221

38 Ídem, pp. 215-217.

39 RODRÍGUEZ MARTÍNEZ, L.: Historia del Monasterio de San Benito el Real de Valladolid. Valladolid, 1971, p. 248.

40 BALADRÓN ALONSO, J.: "El escultor..," op. cit. p. 217.

41 Ídem, p. 220

2 Ídem, pp. 218-219.

43 http://ceres.mcu.es/pages/Main
Santa Brígida, mismo templo al que quizás perteneció el magnífico San Miguel venciendo al demonio que se exhibe en el Museo Nacional de Escultura ${ }^{44}$. En la iglesia de Santa María de Tordesillas (Valladolid) le pertenecerá un dulzón San José con el Niño $o^{45}$, y en Cevico de la Torre (Palencia) un San Juan Bautista ${ }^{46}$. Otras tres obras se le adjudican en tierras zamoranas. Se trata de sendas efigies de San Ignacio de Loyola en Fuentesecas ${ }^{47}$ y en la iglesia de Santa María de la Cuesta de Vezdemarbán ${ }^{48}$, y una Magdalena penitente en la iglesia de San Ildefonso de la capital que copia el modelo popularizado por Pedro de Mena ${ }^{49}$.

Para ofrecer un completo panorama de su actividad artística no podemos dejar de reseñar las esculturas de San Benito, Alfonso III y Alfonso VI del Monasterio de San Benito de Sahagún ${ }^{50}$; y dos obras de menor importancia como fueron la ejecución en 1743 de una Cabeza de San Antonio de Padua y un Niño Jesús para la iglesia de San Juan Bautista de Tordesillas (Valladolid) ${ }^{51}$, y la composición efectuada en 1745 al Cristo de los Entierros y a su retablo, propiedad de la Cofradía de la Vera Cruz de Tordesillas (Valladolid) ${ }^{52}$.

\subsection{Estilo}

El estilo de Felipe de Espinabete evolucionó al ritmo de los tiempos -transitando desde una mezcla de Barroco y Rococó hasta el Neoclasicismo- aunque manteniendo, casi de manera inmutable, una serie de estilemas. En su producción se perciben tres grandes etapas:

La primera, que abarcaría hasta finales de la década de 1750, es difícil de diseccionar debido a la falta de obras acreditadas. Tal es así que de estos años iniciales de maestría tan solo conocemos las esculturas del retablo mayor de la iglesia de San Martín de Arévalo

44 WATTENBERG, F.: op. cit., p. 69

45 BALADRÓN ALONSO, J. "El escultor...", op. cit., pp. 223-224.

46 BALADRÓN ALONSO, J.: Los Ávila. Una familia de escultores barrocos vallisoletanos [Tesis doctora inédita]. Valladolid, 2006, pp. 687-688.

47 NAVARRO TALEGÓN, J.: Catálogo..., op. cit., p. 313

48 Ídem, p. 406

49 RIVERA DE LAS HERAS, I. A.: "Santa María Magdalena Penitente". En VV.AA.: Las Edades del Hombre. El árbol de la vida. Salamanca, 2003, pp. 404-405.

50 CAMPOS SÁNCHEZ-BORDONA, M. D. "La reforma " op. cit, p. 221

51 ARA GIL, C. J. y PARRADO DEL OLMO, J. M.: op. cit., p. 268.

52 GARCÍA MARTÍN, E.: “Las cofradías de Tordesillas en el siglo XVIII". En REDONDO, J., BAZÁN, P. y GARCÍA, A. M.: Tordesillas a través de su Semana Santa, Valladolid, 2000, p. 33 
(1753). En estos momentos sus estilemas más característicos aún no han terminado de aflorar, mostrando una maniera deudora de Pedro de Ávila, su hipotético maestro. Aun así, ya observamos sus peculiares ojos diminutos, la nariz ancha de tabique recto y aplastado, la utilización de un canon alargado y la disposición en contrapposto. Por contra, se perciben unos pliegues enroscados rugosos y bastante toscos (San Martín) y otros acuchillados de escaso resalte (Santa María de la Cabeza) que no serán nada habituales en su plástica.

Un nuevo periodo se iniciaría hacia 1760 con la Cabeza de San Pablo del Monasterio de Nuestra Señora de Prado. Espinabete ya ha alcanzado la maestría tal y como puede comprobarse en el virtuosismo del modelado y en el extremado realismo obtenido a través de un perfecto estudio de las calidades -especialmente reseñable es la captación de la blandura de la piel-. Asimismo, ya aparecen de forma definitiva los estilemas que configuran su característica maniera. Así, las cabezas tenderán al formato rectangular, presentando ojos muy pequeños y achinados y con el lacrimal recurvado, nariz ancha de tabique recto y aplastado con fosas y aletas perfectamente definidas, boca entreabierta con el interior tallado -en ellas se aprecian los dientes y la lengua-, y cejas rectas, aunque cuando se representa algún tormento éstas se enarcan ostensiblemente para figurar un profundo dolor. Los bigotes y las barbas son inconfundibles: los bigotes los dibuja a través de dos finos y sinuosos hilillos de pelo, mientras que las barbas obedecen genéricamente a dos tipos: bífidas de escaso resalte a ambos lados del rostro pero que rematan en el mentón en dos pequeños "cuernecillos" simétricos separados y con las puntas inferiores afrontadas; o largas con ampulosos mechones ramificados compuestos por una sucesión infinita de curvas y contracurvas. En ambos casos cuando la obra es personal el uso del trépano es intenso, de suerte que crea amplias oquedades. En cuanto al cuero cabelludo, éste suele disponerse en mechones mojados asimétricos de diferentes tamaños.

También son bien representativos de esta época los relieves de la sillería del Monasterio de la Santa Espina (1766), el Cristo atado a la columna de Tordesillas (1768), el San Francisco en Oración (ca. 1773) o el San Antonio Abad (ca. 1761-1762) (Fig. 1). En todas estas obra se observa esa concepción ondulante, rítmica y curvilínea que imprime Espinabete a sus composiciones, además de su característico plegado -unas veces el acuchillado procedente de Pedro de Ávila y otras el serpenteante de Pedro de Sierra- que aporta mayor dinamismo y un aspecto pictórico a las superficies a causa de los claroscuros que forman. Cuando la ocasión lo permite, caso de la Magdalena recostada del Museo Nacional de Escultura, se recrea en el preciosísimo, en la anécdota y en una elegancia de raigambre rococó, ayudándose para ello de suntuosas policromías florales y doradas, motivos arrocallados, labores de puntillado y piedras embutidas.

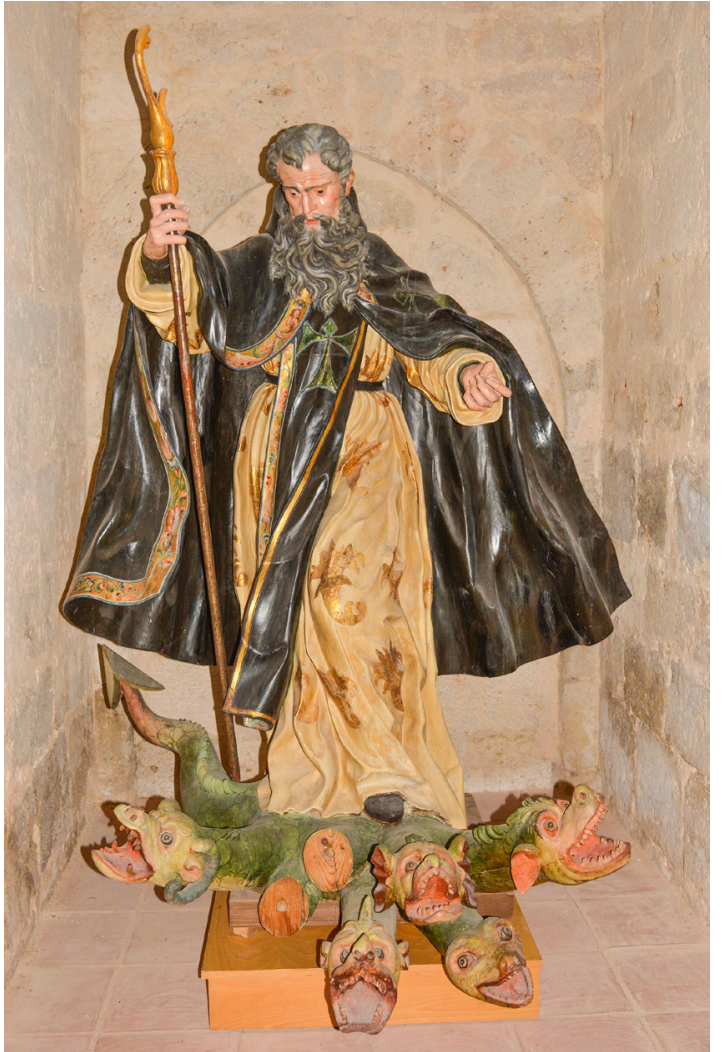

Fig. 1: San Antonio Abad. Felipe de Espinabete (atr.). Hacia 1761-1762 Monasterio de Santa María de Valbuena. San Bernardo (Valladolid)

La última etapa continuó por los mismos derroteros que la anterior, aunque trajo como novedad la influencia neoclásica -hay que tener en cuenta su convivencia con otros escultores decididamente neoclásicos como Pedro León Sedano, y también su ingreso en la Real Academia de la Purísima Concepción de Valladolid en 1784-, patente en las actitudes sosegadas, movimientos reposados y pliegues atemperados de perfil redondeado. Así lo observamos en el San Francisco (1787) de Tordesillas o en el Salvador de la homónima iglesia vallisoletana. 


\section{NUEVAS ATRIBUCIONES}

2.1. San Ramón Nonato (1742). Iglesia de Santo Tomás. Vallelado (Segovia)

La primera obra que le adjudicamos es el excelente San Ramón Nonato (Fig. 2) de la iglesia de Santo Tomás de Vallelado (Segovia), que fue realizado en 1742 gracias a las limosnas donadas por los fieles del santo ${ }^{53}$. San Ramón (1203-1240), que fue un santo mercedario catalán cuyo apodo "Non natus" (no nacido) procede del hecho de que nació por cesárea después de que falleciera su madre, es representado erguido y con el cuerpo recurvado, huyendo de toda simetría y frontalidad. Coloca los pies en un ángulo de $90^{\circ}$ a la manera de Pedro de Ávila. El dinamismo compositivo se incrementa con la apertura del brazo derecho, en cuya mano sostendría una custodia o expositor que hace referencia al viático recibido de manos de Cristo, aunque en otras ocasiones se señala que se lo entregó un ángel; por su parte, posa la mano derecha sobre el pecho en actitud declamatoria a la vez que porta la palma del martirio, que alude a las torturas sufridas a manos de los musulmanes, con tres coronas que hacen referencia a sus tres virtudes (castidad, elocuencia y martirio). Las prendas (túnica, sobretúnica y una esclavina roja abrochada al cuello) presentan una serie de pliegues frapeantes y violentamente ondeados por efecto del viento. Se trata de unos plegados en zigzag que, aunque parten del acuchillado, están más cercanos al serpenteante del Rococó, uno de cuyos cultivadores fue Pedro de Sierra, de quien pudo aprenderlo. Asimismo, coincide con Sierra en la actitud elegante y en la concepción de una cabeza proporcionalmente pequeña en relación con el resto del cuerpo, rasgo estilístico que el riosecano asimilaría durante sus años de estudio en La Granja junto a los escultores franceses René Frémin (1672-1744) y Jean Thierry (1669-1739). En la cabeza del santo, que emparenta con la del relieve de San Francisco de la sillería de legos del Monasterio de San Benito, ya se aprecian algunos de los estilemas de Espinabete: blandura en el rostro, cejas rectas, nariz ancha de tabique recto, bigotes formados por finos y sinuosos hilillos de pelo, barba bífida con puntas afrontadas, etc.

53 ARRANZ SANTOS, C. y FRAILE DE PABLO, A.: Historia de Vallelado, tierra de Cuéllar. Valladolid, 1998, p. 154

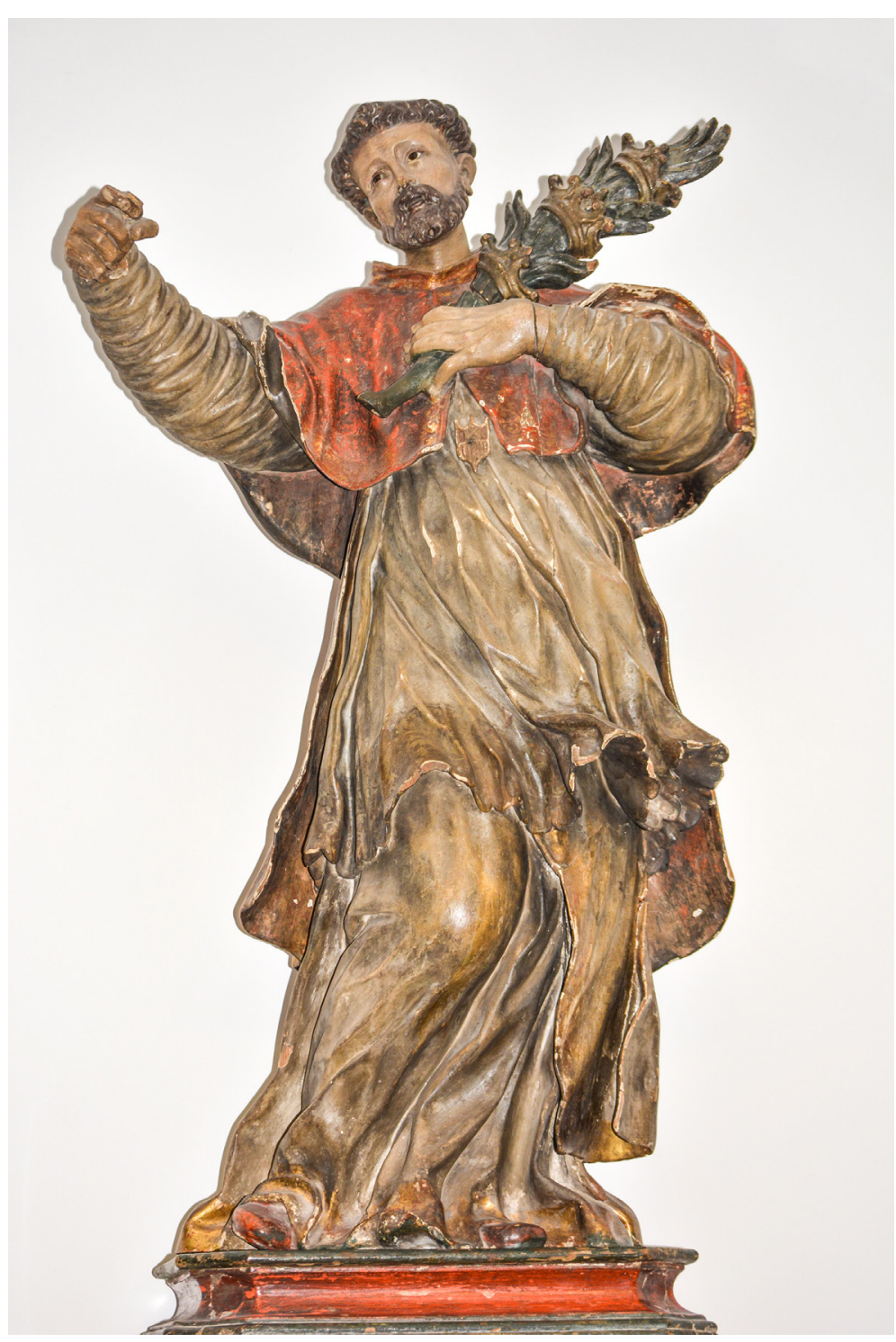

Fig. 2: San Ramón Nonato. Felipe de Espinabete (atr.). 1742. Iglesia de Santo Tomás. Vallelado (Segovia) 
2.2. San Miguel venciendo al demonio (ca. 1753-1756), San José con el Niño (¿ca. 1753-1764?), y Virgen del Carmen (ca. 1764). Iglesia de San Miguel. San Miguel del Arroyo (Valladolid)

En el retablo mayor de la parroquial de San Miguel del Arroyo (Valladolid) le pertenecerán las tres esculturas del mismo: San Miguel derrotando al demonio, San José con el Niño, y la Virgen del Carmen. El retablo, que consta de banco, cuerpo con tres calles y ático de remate semicircular, fue contratado el 9 de diciembre de 1753 por el prolífico ensamblador y tallista iscariense Domingo Fernández Pedrosa, que se obligó a fabricarlo "en el precio [6.600 reales] y con las calidades y condiciones que el susodicho ha dispuesto y firmado en cuatro hojas de papel común con fecha del día treinta de dicho mes de noviembre, y con arreglo a una traza y diseño" ${ }^{24}$. En las condiciones se comprometía además a fabricar un trono para la hornacina principal con las jambas "moldadas bien talladas de buenos adornos, y así también los cinco frisos que corresponden a la porción bien tallados ha de llevar dicha caja otra contracaja más interior en porción cóncava guarnecida con su concha". También correría a su cargo la "efigie de San Miguel" (tarea que subarrendaría a un escultor) que debía de ocupar el trono, así como la policromía de éste con "ropas naturales con sus orillas de oro en sus ropajes, plata y oro en los petos, morrión, turbante". La escultura debía de medir "vara y media escasa" y estar de "pie en su postura fuerte sobre la sierpe infernal". El ensamblador también se comprometía a llevar a cabo "las dos cajas para dos santos" -se tenía pensado reaprovechar dos esculturas de San Ramón Nonato y San Sebastián-, y la pintura "en tabla de los dos santos apóstoles que dicho señor eligiere" del ático, que efigia a San Andrés y Santiago.

Tras finalizar la parte arquitectónica del retablo se procedió en 1757 a dorar "la mesa de altar, cascarón, gradas y tarjetas" ${ }^{\prime 5}$, tarea que corrió a cargo del dorador lucense José Esteban Bermúdez de Riobóo ${ }^{56}$, y en 1768 el dorador cuellerano Dionisio Nieto se ocupó de dorar las tres hornacinas del retablo ${ }^{57}$. En 1799 el retablo sufrió una completa remodelación ya que el también dorador cuellerano Luis Benavides doró y estucó el retablo para, mediante

54 A.H.P.V., Leg. 10.529, ff. 470-476,

55 BRASAS EGIDO, J. C.: Catálogo Monumental de la provincia de Valladolid. Tomo X. Antiguo partido judicial de Olmedo. Valladolid, 1977, p. 204.

56 Probablemente el dorador era amigo de Domingo Fernández Pedrosa dado que ambos procedían de

Lugo. El ensamblador era natural del lugar de San Lázaro, arrabal de Mondoñedo (Lugo). BRASAS EGIDO, J. C.: Catálogo..., op. cit., p. 202

57 Ídem, p. 204 la simulación de materiales nobles (mármoles, jaspes y bronce), adaptar su estética a los nuevos gustos del Neoclasicismo ${ }^{58}$, y el tallista vallisoletano Eustaquio Bahamonde fabricó un tabernáculo y mesa de altar a la moda ${ }^{59}$, elementos actualmente desaparecidos.

La escultura de San Miguel derrotando al demonio (Fig. 3) sigue el modelo creado por el escultor iscariense Alejandro Carnicero $(1693-1756)^{60}$, no siendo la única ocasión en que Espinabete trató esta iconografía puesto que le tenemos documentadas las efigies que realizó para la iglesia de San Nicolás de Valladolid (ca. 1766), y para la parroquial de Solana de Rioalmar (Ávila) (1778-1779). Asimismo, se le atribuye otra en el Museo Nacional de Escultura que resulta ser bastante similar a la que estamos tratando.

La composición es muy teatral y se halla dominada por la diagonal, que se ve implementada por el manto rojo. El movimiento es muy precipitado, de suerte que el escultor capta perfectamente el instante en que el Arcángel se dispone a sentenciar a Lucifer. El Arcángel colocado en una posición inestable, viste atuendo de guerrero con coraza de escote cuadrado ajustada al cuerpo y yelmo de airoso penacho en la cabeza. El manto está surcado de pequeños pliegues a cuchillo. El rostro presenta los estilemas de Espinabete si bien no tan pormenorizados como en otras ocasiones. En la mano derecha empuñaría la espada, mientras que en la izquierda haría lo propio con un escudo. La presente escultura es la más próxima desde el punto de vista iconográfico al prototipo de Carnicero puesto que es la única que copia la acrobática y dinámica postura del demonio, así como su fisionomía -ya que en el resto les otorga un aspecto más serpentiforme que humano- y pequeños detalles como la serpiente enroscada en la pierna.

Por su parte, la escultura de San José con el Niño (Fig. 4) tampoco presenta problemas para su adjudicación a Espinabete puesto que se trata de una copia de la que se le atribuye en la iglesia de Santa María de Tordesillas ${ }^{61}$. La única diferencia reseñable es que en aquella

8 Ibídem

59 Ibídem.

60 Aunque el ejemplar más descollante de San Miguel labrado por Alejandro Carnicero es el que realizo para el Hospital de San Miguel de Nava del Rey (Valladolid) en 1736, son anteriores a éste los que tallo hacia 1727 para la iglesia de Santa María de Alaejos (Valladolid) y en 1735 para Tarazona de Guareña (Salamanca). Esta iconografía creada por Carnicero aunque con antecedentes talasos tanto en puntura (Salamanca). Esta icon como escula se hiz bien cón escultor Alejandro Carnicero entre Valladolid y la Corte (1693-1756). Valladolid, 2012, p. 236. 61 BALADRÓN ALONSO, J.: “El escultor...", op. cit., pp. 223-224. 


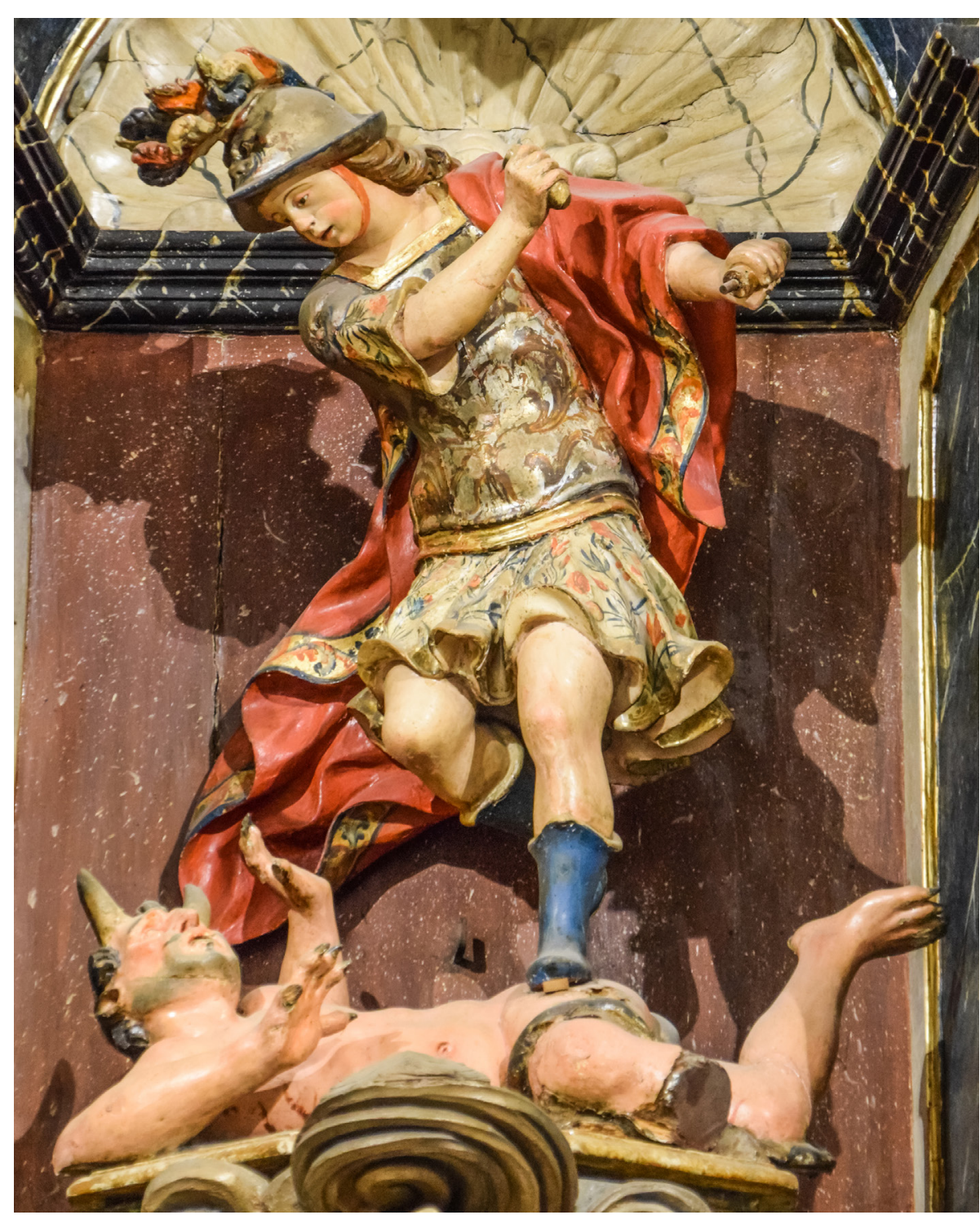

Fig. 3: San Miguel venciendo al demonio. Felipe de Espinabete (atr.). Hacia 1753-1756. Iglesia de San Miguel. San Miguel del Arroyo (Valladolid)

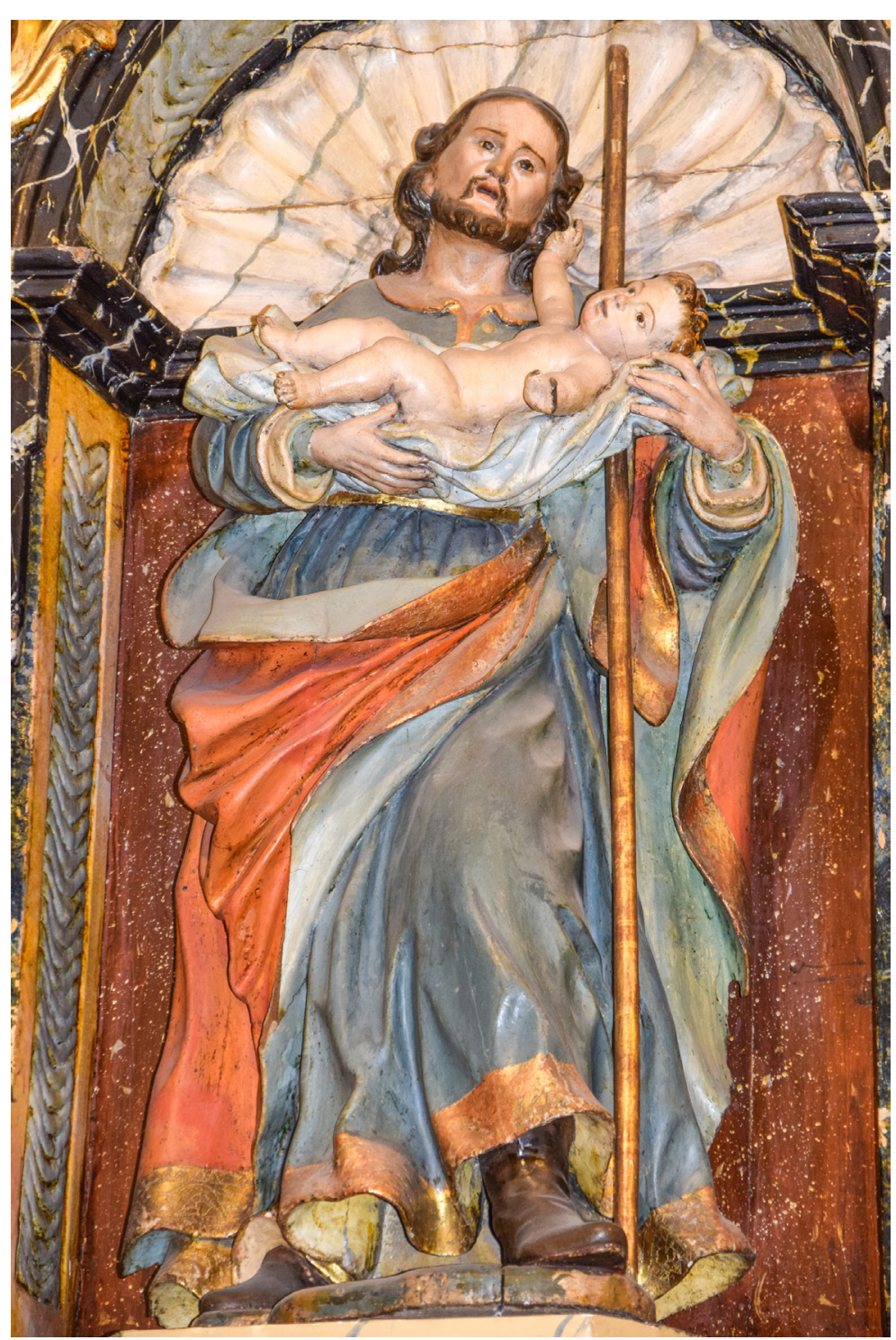

Fig. 4: San José. Felipe de Espinabete (atr.). Hacia 1753-1764. Iglesia de San Miguel. San Miguel del Arroyo (Valladolid) 
San José agarra directamente a su Hijo, mientras que en esta que nos concierne el Niño va recostado sobre un pañete que su Padre sujeta por ambos lados, de suerte que no llega a tocarle. Se trata de una imagen elegante a la par que dotada de una gracia puramente dieciochesca. El patriarca baja la cabeza para mirar a su Hijo, a lo que éste corresponde con una sonrisa y acariciándole la cara. El rostro, que posee numerosas afinidades con el del San José que se le adjudica en San Román de Hornija ${ }^{62}$, presenta los típicos estilemas de Espinabete: ojos pequeños con el lacrimal recurvado, nariz ancha de tabique recto, bigotes de finos pelillos, barba bífida de mechones afrontados, y melena formando grandes ondulaciones. El Niño posee una anatomía rolliza y cabeza con mechones revueltos. Desconocemos su fecha de ejecución, aunque la presencia de pliegues acuchillados en el manto y en la túnica indicaría que se realizó dentro de los primeros años de maestría del escultor, en fecha cercana al San Miguel.

Finalmente tenemos la Virgen del Carmen ${ }^{63}$ (Fig. 5), imagen que presenta algunas dudas para su atribución a pesar de que el Niño es similar al que acompaña a San José, y que la Virgen es casi idéntica a la que el propio Espinabete talló para Solana de Rioalmar (17781779). El 28 de enero de 1764 don Nicolás Antonio Moreno, cura y beneficiado de preste de la parroquia, bendijo la imagen, que fue colocada el 25 de febrero de ese mismo año en su altar ${ }^{64}$. La Virgen figura de pie, con una pierna izquierda levemente adelantada. Con la mano izquierda sujeta al Niño Jesús mientras que con en la otra porta un escapulario, mismo elemento que exhibe su Hijo en su mano izquierda. Viste hábito carmelita con túnica y escapulario marrón con rica cenefa dorada en el borde. Por encima una capa abrochada al cuello. Las vestimentas están recorridas por sinuosos pliegues ya plenamente rococós. La cabeza muestra un rostro bastante inexpresivo pero que presenta algunas de las características del tordesillano como los ojos pequeños y la cabellera de bucles serpenteantes. El Niño, que va desnudo y sería imagen de vestir, mira dulcemente a su Madre y le otorga su bendición.
62 Ídem, pp. 221-222.

63 Sigue el tipo iconográfico ideado por Gregorio Fernández y cuyo ejemplar más conocido fue el ejecutado para el Convento del Carmen Calzado de Valladolid en 1627

64 BRASAS EGIDO, J. C.: Catálogo..., op. cit., p. 204.

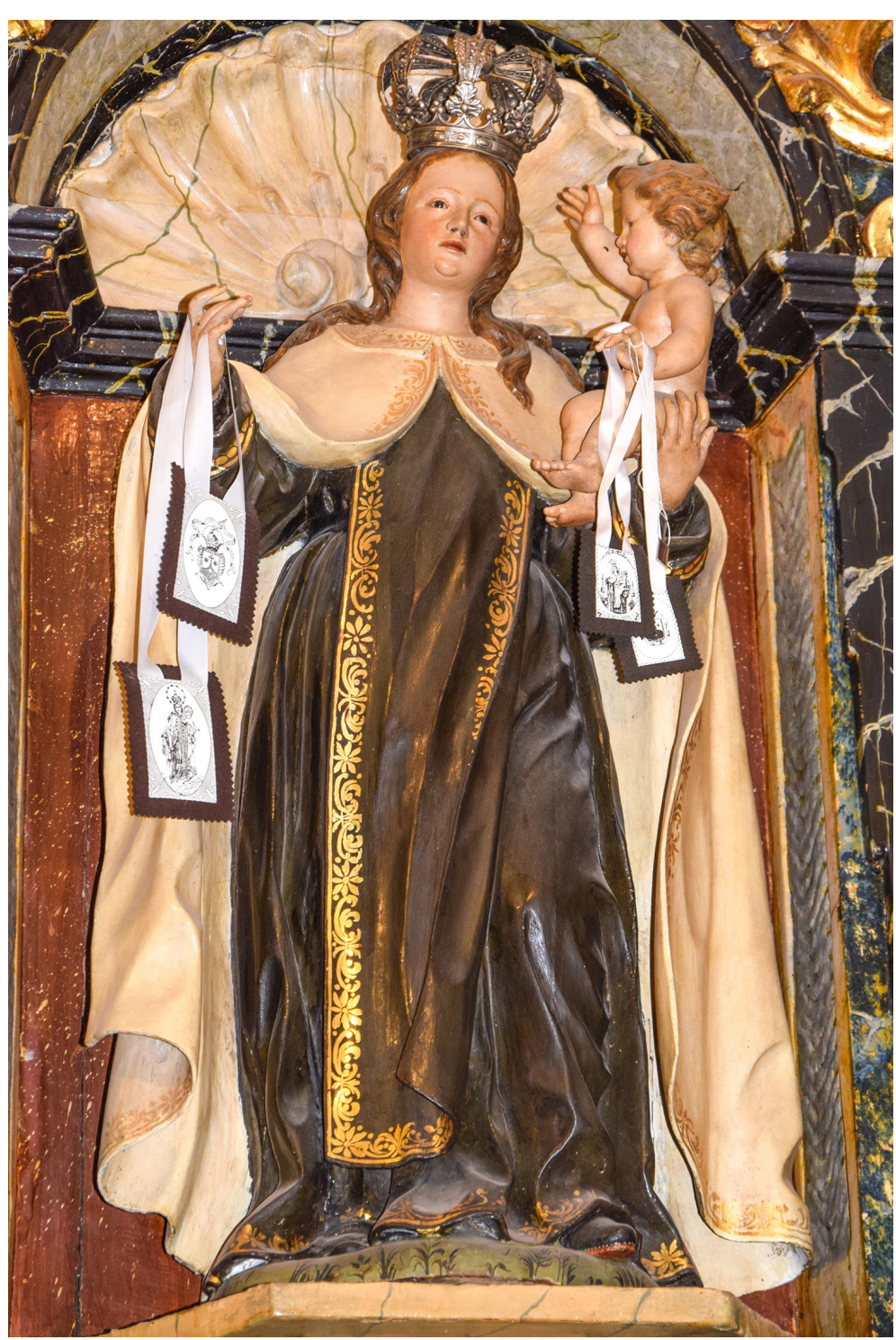

Fig. 5: Virgen del Carmen. Felipe de Espinabete (atr.). Hacia 1764. Iglesia de San Miguel. Sa Miguel del Arroyo (Valladolid) 


\subsection{San Agustín y San Ambrosio (ca.1761-1762). Catedral. Valladolid}

En 1246 los Antonitas o Hermanos Hospitalarios de San Antonio, orden religiosa que tenía por referente a San Antón Abad (251-356), fundaron en Valladolid un hospital que "está incorporado o adjunto con el colegio de San Ambrosio de padres jesuitas; en él curaban antiguamente muchos pobres que padecían cáncer y otro achaque de este género" ${ }^{35}$. La iglesia se construyó entre 1541-1543 por el maestro de cantería Pedro de la Henestosa gracias a la generosidad de doña Francisca de Taxis. Con el paso del tiempo el templo sufrió una serie de ampliaciones y modificaciones e incluso en 1722 se fundó una cofradía puesta bajo la advocación del santo ${ }^{66}$.

El 22 de julio 1761 dicha cofradía se ajustó con el ensamblador Agustín Martín para que construyera un nuevo retablo mayor y custodia ${ }^{67}$. Martín, que percibiría por su hechura la nada desdeñable cantidad de 8.200 reales, se comprometía a tenerlo acabado en el plazo de un año. Según las condiciones y trazas presentadas por el ensamblador, pero que habían sido diseñadas por su hijo Fernando Martín, asimismo maestro ensamblador, se reutilizarían para el cuerpo de dicho retablo "dos historias de medio relieve y dos lienzos de los que hay en el retablo viejo". En el cerramiento, que tendría tres hornacinas, se debían colocar a los lados "dos santos que se hallan en la cornisa del retablo viejo", y en la caja de medio "donde está diseñada la cruz" una imagen de Nuestra Señora de la Asunción que también provendría del antiguo retablo, que había sido fabricado en 1553 por los escultores medineses Diego Rodríguez y Leonardo de Carrión ${ }^{68}$. El retablo, que combinaba escultura -tanto en relieve como en bulto redondo- y pintura se estructuraba a través de dos grandes columnas en los extremos, acogiendo en su interior un banco, dos cuerpos con tres calles y el ático. En el banco encontraban asiento dos relieves efigiando sendas tentaciones de santo eremita, y entre ambos, ocupando la calle central del banco, se hallaba el sagrario. En esta misma calle, encima del sagrario había un relieve del Noli me Tangere, sobre él una Asunción rodeada de ángeles, y coronando esta calle la Trinidad, aunque la efigie del Hijo se

65 CANESI ACEVEDO, M.: Historia de Valladolid (1750), Tomo II. Valladolid, 1996, p. 71

66 İdem, p. 72.

67 A.H.P.V., Leg. 3.703, ff. 161-163. Ambas partes cumplieron lo pactado, de tal manera que el 24 de agosto de 1762 el ensamblador otorgó carta de pago. BALADRÓN ALONSO, J.: "Nuevas obras de Francisco Díez de Tudanca y otros datos de escultores barrocos vallisoletanos", BSAA Arte, № 78, 2012, p. 169.

68 Ambos maestros debían de ocuparse tanto de la parte arquitectónica como de la escultórica, las cuatro pinturas que lo completaban y el dorado de la máquina fueron ejecutados en 1559 por Jerónimo Váz quez y Gaspar de Palencia. MARTÍ Y MONSÓ, J.: op. cit., pp. 214-216. hallaba representado por un Crucificado al que acompañaban San Juan y María. En el ático, flanqueando a la Trinidad, asentaban en los extremos las efigies de San Pedro y San Pablo. Completaban el conjunto en las calles laterales de ambos cuerpos cuatro pinturas sobre tabla (la Oración del Huerto, el Descendimiento, la Ascensión y un episodio desconocido).

Una vez fabricado el retablo rococó, que no llegaría a dorarse puesto que cuando González García-Valladolid lo admiró hacia el año 1900 éste se hallaba "en blanco"69, se retiraría el renacentista y se colocaría en otra parte del templo, ya fuera fragmentariamente o en su totalidad -en una fotografía del inédito Catálogo Monumental de la Provincia de Valladolid redactado por Francisco Antón se observa parte del retablo dispuesto frente a la capilla de los Calatayud ${ }^{70}$-. Este nuevo retablo, que como ya dijimos tenía previsto incorporar algunas esculturas y relieves del primitivo, traía como novedades la custodia, que estaría conformada por columnas estriadas sujetando un cascaron que se podía "abrir y desabrir", y una nueva escultura de San Antonio Abad para la hornacina principal, imagen atribuida a Felipe de Espinabete ${ }^{71}$. Finalmente, hubo más cambios de los previstos puesto que no se llegaron a reaprovechar todas las esculturas, relieves y pinturas que se pensaba. Así, nos consta por un "Inventario de alhajas y muebles que de la pertenencia de la Excelentísima señora Vizcondesa de Valoria existen en la iglesia de San Antonio Abad de Valladolid" realizado hacia el año 1900 -quizás 1906- que el retablo estaba compuesto por "las efigies de San Antonio Abad, San Agustín, San Ambrosio, San Joaquín y Santa Ana y Nuestra Señora de la Asunción y demás que constituyen dicho altar mayor"72. Es decir, la imagen principal de cada piso se veía acompañada por otras dos: San Antonio Abad por San Agustín, cuya Regla seguía la orden Antonita, y San Ambrosio, quizás por lindar el templo con el jesuita Colegio de San Ambrosio; mientras que la Asunción estaría flanqueada por sus padres, San Joaquín y Santa Ana.

69 GONZÁLEZ GARCÍA-VALLADOLID, C.: Valladolid, sus recuerdos y sus grandezas: religión, historia ciencias, literatura, industria, comercio y política, Tomo I. Valladolid, 1900, p. 709.

$70 \mathrm{http}: / /$ biblioteca.cchs.csic.es/digitalizacion_tnt/index_interior_valladolid.html.

71 URREA, J.: "Nuevos datos...", op. cit., p. 511; VELASCO GALLEGO, S.: "San Antonio Abad". En

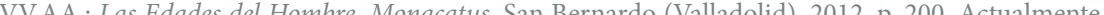
V.AA. Las Edes del Ho con Catho Mosu E.: Catálogo Monumental de la provincia de Valladolid. Tomo VIII. Antiguo partido judicial de Peñafiel. Valladolid, 1975, p. 304

72 A.G.D.V., Valladolid, Santísimo Salvador, Cofradía de la Piedad, Libro 11, Varios. 
Ambos Padres de la Iglesia son retratados erguidos en idéntico ademán, de suerte que elevan el brazo derecho, en cuya mano sostendrían un báculo, mientras que con la izquierda sujetan un volumen cerrado (San Ambrosio) y un libro que sirve de peana a la maqueta de una iglesia (San Agustín) (Fig. 6), símbolo de fundador de una Orden religiosa. Visten túnica, roquete, capa pluvial y tiara de acuerdo a su condición de obispos. A pesar de la frontalidad con la que han sido concebidos, Espinabete ha sabido dotarles de dinamismo a través del contrapposto, y de una composición abierta y asimétrica basada en la disposición de las articulaciones en distintos planos y alturas. La utilización en la parte baja de las túnicas de pliegues muy aristados también les aporta vitalidad, al tiempo que les confiere un carácter pictórico. En ellos se observan los clásicos estilemas del primer Espinabete, ya referidos con anterioridad. Además, la efigie de San Agustín resulta ser una versión previa del que acometerá años después para La Seca (Valladolid) ya que mantiene la misma disposición, vestimentas y plegados, diferenciándoles tan solo el hecho de que el ejemplar lasecano ya muestra una cabeza plenamente espinabetiana con sus típicos ojos con los lacrimales recurvados, uno de los elementos definitorios de su plástica. Aún hay un detalle más que apoya esta adscripción a Espinabete: la similitud que guardan las ampulosas barbas de ambos santos con la que exhibe San Antón, si bien el acabado no es tan minucioso y pormenorizado.

En cuanto a Santa Ana, y aunque compositivamente es idéntica a los Padres de la Iglesia, con los que además comparte el mismo sistema de plegados y de peana, no es posible adjudicársela a Espinabete pues su rostro difiere en demasía de sus planteamientos formales, por lo que quizás se trate de una obra de taller, o bien habría que pensar que la parte escultórica del retablo hubiera corrido a cargo de dos maestros, quedándose Espinabete con la ejecución de las efigies del primer cuerpo (San Ambrosio, San Antón y San Agustín), y el otro maestro con las del segundo (San Joaquín, la Asunción y Santa Ana). La madre de la Virgen porta una túnica negra idéntica a la de los Padres de la Iglesia un manto que forma una diagonal sobre el cuerpo de la santa, y una toca que le enmarca el rostro y le recoge la cabellera. Gira el rostro hacia la izquierda, al mismo tiempo que se lleva la mano izquierda al pecho como en actitud de sometimiento, mientras que la otra la extiende realizando un gesto declamatorio. Posiblemente, en el retablo se encontraría observando a la Asunción.

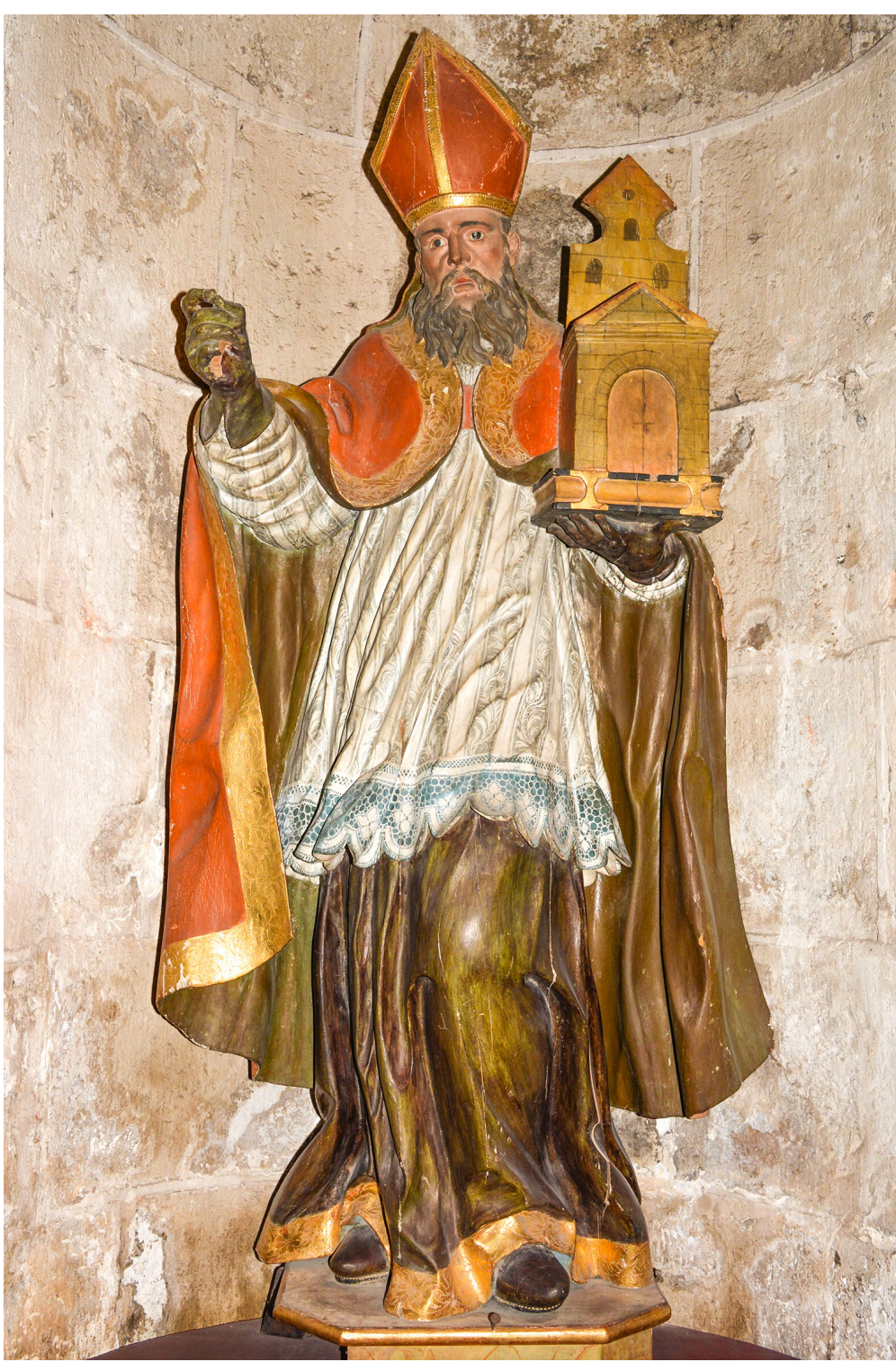

Fig. 6: San Agustin. Felipe de Espinabete (atr.). Hacia 1761-1762. Catedral. Valladolid 
2.4. San Diego de Alcalá y San Simón de Rojas (ca. 1766). Museo de San Antolín. Tordesillas (Valladolid)

Corresponderán a Espinabete dos pequeñas esculturitas de San Diego de Alcalá $(60 \mathrm{~cm})$ y de San Simón de Rojas (Fig. 7) que, conservados en el Museo de San Antolín, proceden de una capilla del lado del Evangelio de la iglesia de San Juan Bautista ${ }^{73}$. Sin duda se tratará de obras de taller dado el tratamiento sumario de las superficies, la evidente desproporción de ciertos miembros (véanse las manos de San Diego) y el carácter estereotipado e insípido de los rostros. A pesar de todo la efigie de San Simón de Rojas, especialmente su rostro, es de mayor calidad que la de San Diego de Alcalá. Ambos santos figuran en contrapposto y revestidos con el hábito de su Orden. San Diego extiende la mano derecha realizando un gesto declamatorio, mientras que con la otra sujeta unas flores que porta entre los pliegues de su manto y que aluden a su conocido milagro. Por su parte, San Simón ha perdido la mano derecha e incluso los atributos (custodia y rosario). La escultura de San Simón parece copiar a la que existió en la catedral de Valladolid, quizás la que se utilizó durante las celebraciones de su beatificación, y que hoy se encuentra en la iglesia de su mismo nombre en el barrio de Covaresa. En cuanto a la cronología de ambas piezas pudiera situarse hacia 1766, año en el que el Papa Clemente XIII beatificó al santo vallisoletano.

2.5. San Pedro Pascual y San Serapio (ca. 1780). Iglesia parroquial de San Pedro. Valdunquillo (Valladolid)

La iglesia de San Pedro, antiguo Convento de Nuestra Señora de la Merced Descalza levantado en el siglo XVIII, de la localidad terracampina de Valdunquillo (Valladolid) está presidida por un elegante retablo rococó en cuyas calles laterales encuentran asiento dos efigies de San Pedro Pascual y San Serapio que no dudamos tampoco en atribuir a Espinabete. La máquina, claro ejemplo de magno retablo rococó, exhibe cuatro grandes columnas clásicas con el tercio inferior tallado y los otros dos estriados y plagados de cabezas aladas de angelotes y rocallas estilizadas. Cada una de estas columnas se sustenta

73 MARTÍN GONZÁLEZ I. J (dir): Inventario artístico de Valladolid y su provincia Valladolid, 1970 lizó el Catálogo Monumental presbiterio de la iglesia de San Antolín. Hasta su localización actual en la mesa del retablo colateral de la epístola, ambas imágenes han sufrido varios cambios de ubicación en el templo. ARA GIL, C. J. y PARRADO DEL OLMO, J.M.: op. cit., p. 156

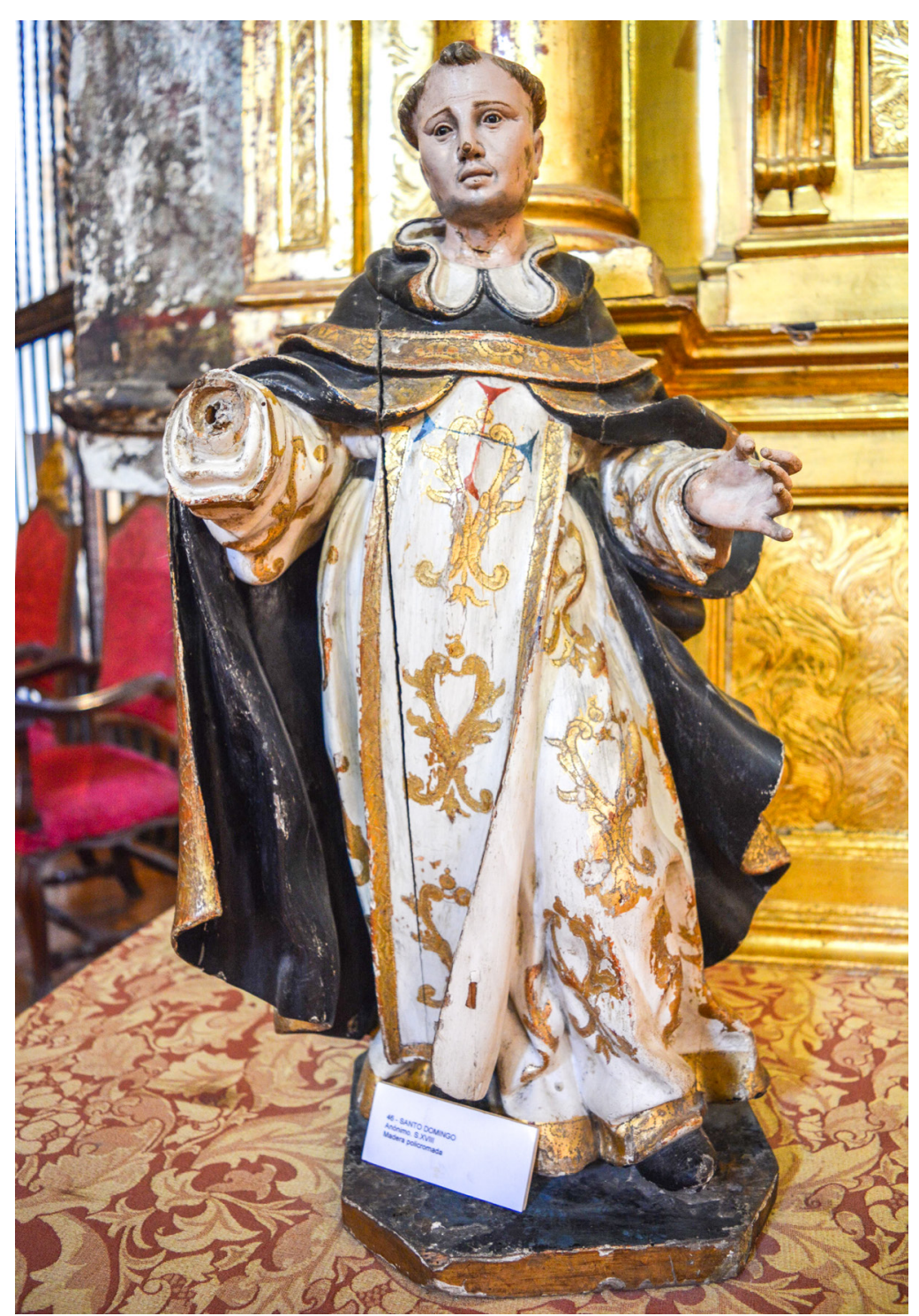

: San Simón de Rojas. Felipe de Espinabete (atr.). Hacia 1766. Museo de San Antolín. Tordesillas (Valladolid) 
en potentes pedestales recubiertos de rocallas y otros elementos vegetales entre los cuales juguetean cuatro grandes ángeles que hacen función de atlantes. Entre estas ménsulas situadas en el banco se hallan el tabernáculo en el centro y dos netos que contienen sendos relieves de formato rectangular de temática mercedaria (la Aparición de la Virgen de la Merced a San Jaime y a San Pedro Nolasco, y la Muerte de San Pedro Nolasco $)^{74}$.

La calle central está presidida por una gran hornacina de remate semicircular cubierta por un pabellón y que exhibe, cual retablo-escenario, un grupo de la Anunciación o de la Encarnación (antigua titular del convento) con una puesta en escena muy teatral del Arcángel sobrevolando y la Virgen encima de un escaño. Las calles laterales se distribuyen en dos pisos, en el inferior tienen cabida dos grandes hornacinas también de remate semicircular flanqueadas por sendas columnas de fuste liso con tercio tallado y algunas rocallas estilizadas. En su interior figuran San Pedro Pascual y San Serapio. Sobre estas hornacinas dos medallones o clípeos rematados en pabellones similares a los del grupo de la Encarnación que contienen sendos relieves de santos mercedarios, el de la izquierd aparece revestido de pontifical y con unas nubes sobre la cabeza, mientras que el de la derecha (San Pedro Armengol) empuña un Crucifijo y lleva al cuello la soga de su martirio.

De este amplio conjunto de temática mercedaria las únicas esculturas que pueden relacionarse con Espinabete, siendo además de altísima calidad, son las de San Pedro Pascual y San Serapio. Por el contrario, ni los relieves del banco, ni los de los clípeos, ni los ángeles del ático, y ni siquiera el San Pedro en cátedra ${ }^{75}$ pueden asignársele. San Pedro Pascual (ca.1227-1300) fue uno de los intelectuales de la Orden Mercedaria, tal es así que tras haber sido apresado por los musulmanes escribió numerosas obras en la cárcel. Se distinguió por haberse adelantado a todos los teólogos occidentales en su defensa del dogma de la Inmaculada Concepción de la Virgen. Posiblemente por esta razón se encuentre flanqueando a la Anunciación. El santo valenciano está de pie en posición de

74 URREA, J. y BRASAS EGIDO, J. C.: Catálogo Monumental de la provincia de Valladolid. Tomo XII. Antiguo partido judicial de Villalón. Valladolid, 1981, pp. 98-99; ALEGRE PASTOR, P.: La historia de Valdunquillo y la Orden de la Merced Descalza. Salamanca, 2005, pp. 141-142.

75 De la efigie del primer Papa sabemos que fue la que presidió el retablo de la antigua parroquia homónima, y que se realizó en 1741 en Medina de Rioseco, siendo policromada por el dorador riosecano

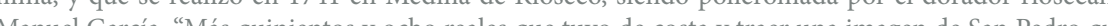

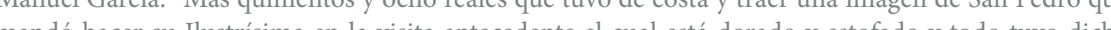
mandó hacer su llustrisina en la isita antecedente el cual está dorado y estofado y todo tuvo dich costa a Manuel García dorador de dicha ciudad de Medina de Rioseco". A.G.D.V., Valdunquillo, San Pedro, Caja 1, Cuentas 1692-1774, f. 148 avance. Viste túnica y sobretúnica blancas y muceta azul. El rostro, que exhibe los clásicos estilemas del escultor, amén de una ampulosa barba y una calva tan solo interrumpida por pequeñas guedejas laterales y un mechoncito circular sobre la frente, posee ecos de la Cabeza de San Pablo del Museo Nacional de Escultura en nariz, ojos, y barba. Asimismo, la manera de definir las cejas, ojos y nariz es similar a las del San Antonio Abad, mientras que la forma de los bigotes y la expresión general del rostro concuerdan con las del San Juan Nepomuceno de la iglesia de la Magdalena de Valladolid. Con la mano izquierda sujeta un libro y probablemente en la derecha empuñó una pluma. Ambos atributos aluden a su citada faceta de escritor doctrinal y teólogo. En el cuello tiene clavado el machete con el que los musulmanes le decapitaron mientras celebraba misa en Granada el 6 de diciembre de 1300. A sus pies un pequeño angelote que ha perdido el atributo que sujetaba con ambas manos, posiblemente una palma del martirio o una mitra que hiciera referencia a su dignidad de obispo de Jaén, cargo al que también alude el báculo.

Por su parte, San Serapio (1179-1240) fue un mártir inglés que se dedicó a predicar en tierras islámicas, llegando a alcanzar numerosas conversiones y a redimir cautivos en Argel. En su última redención se ofreció como parte del pago para liberar algunos cautivos, sin embargo, el dinero para su rescate no llegó a tiempo y fue condenado a morir clavado en una cruz en forma de aspa mientras le extirpaban los intestinos con un torno. Aparece representado según una iconografía muy poco usual, portando el hábito de caballero laico mercedario, con calzas, vestido corto y capa de armiño ${ }^{76}$. Con la mano derecha sujeta la cruz aspada en la que fue martirizado -el propio santo quiso que le crucificaran como a San Andrés- mientras que la izquierda la ha perdido, si bien parece claro que tendría la palma vuelta hacia arriba pues es evidente que Espinabete se inspiró para su ejecución en el San Andrés (1629-1633) que François Duquesnoy talló para uno de los pilares del crucero de la Basílica de San Pedro del Vaticano. Por otra parte, el rostro de Serapio emparenta con el de San Gregorio del Monasterio de San Benito de Valladolid y también con los de los Santos Benedictinos que se conservan en la iglesia de San Miguel de la referida ciudad ${ }^{77}$. Asimismo, el volumen craneal presenta numerosas concomitancias con los de algunos de los santos tallados en la sillería del Monasterio de la Santa Espina (Valladolid), y en la sillería de legos del Monasterio de San Benito el Real. Obsérvense, por ejemplo, las efigies de Santo Tomás, San Bernardo o San Bruno de esta última sillería.

76 ALONSO AGUADO, M.: "San Serapio, mártir. A pequeña escala", Caminos de liberación, № 178, Año 37,2016, p. 9

77 BALADRÓN ALONSO, J.: “El escultor...”, op. cit., p. 217 
Es probable que ambas tallas fueran esculpidas hacia 1780 -fecha que se adecúa a los pliegues calmados que recorren las vestimentas de ambos santos- puesto que el 2 de julio de ese año el dorador vallisoletano Miguel García (1749-1793) ${ }^{78}$ se concertó con el Reverendo Padre Fray Antonio del Espíritu Santo para dorar el retablo mayor y el púlpito de la iglesia del "referido Convento de la Encarnación". Entre las condiciones que se redactaron para su dorado, por el que percibiría 21.500 reales de vellón, observamos algunas que muestran una marcada inclinación por la estética rococó. Así, se especifica que "en todos los vaciados y partes donde corresponda se abrirán varios adornos chinescos de buen gusto y modas", o que "toda la obra ha de ser dorada de oro limpio de Portugal de la fábrica de Madrid de cuerpo y buen color bruñendo lo necesario, y dejando lo que es preciso para bronceado". La finalización de la obra se debió de demorar hasta bien entrado el año 1781 puesto que el dorador bautizó a su hijo Gabino en la parroquia de Valdunquillo el 25 de febrero del dicho año ${ }^{79}$.

\subsection{San Pedro en cátedra (1789). Iglesia de la Asunción. La Pedraja de} Portillo (Valladolid)

En la iglesia parroquial de La Pedraja de Portillo se conserva una interesante efigie de San Pedro en cátedra (1 m) (Fig. 8) que parece claramente atribuible a la última etapa productiva del escultor ${ }^{80}$. La imagen no se realizó para este templo sino para la parroquia de San Pedro de El Cardiel ${ }^{81}$, cuyo retablo mayor presidiría. Por dicha efigie, que se hizo "de orden de su Ilustrísima el Obispo", se abonaron en el año 1789 a un anónimo escultor, creemos que Espinabete, la crecida cantidad de 1.080 reales y 21 maravedíes, lo que da buena prueba de que el autor era un maestro prestigioso ${ }^{82}$.

La escultura copia fielmente el modelo iconográfico ideado por Gregorio Fernández hacia 1630 para los franciscanos del Convento de Santa María de Scala Coeli de El Abrojo, enclave cercano a Laguna de Duero (Valladolid) ${ }^{83}$. San Pedro está sentado en un sillón

8 A.H.P.V., Leg. 3.882, ff. 270-275

9 A.G.D.V., Valdunquillo, San Pedro Apóstol, 1694B, f. 228.

80 BRASAS EGIDO, J.C.: Catálogo..., op. cit., p. 108.

81 Se trata de un despoblado ubicado en el término de La Pedraja de Portillo que quedó destruido durante la Guerra de la Independencia.

82 Hechuras de efigie. "Ítem mil ochenta reales y veinte y un maravedí que ha tenido de costa la hechura de la efigie de San Pedro y retocar otras, cuya obra se ha hecho de orden de su Ilustrísima el Obispo ( $\mathrm{mi}$ señor) consta de recibo". A.G.D.V., Cardiel, San Pedro, Caja 2, Libro de cuentas 1763, f. 29.

83 Como ocurrió con la mayoría de los tipos iconográficos creados por Fernández fue ampliamente re-

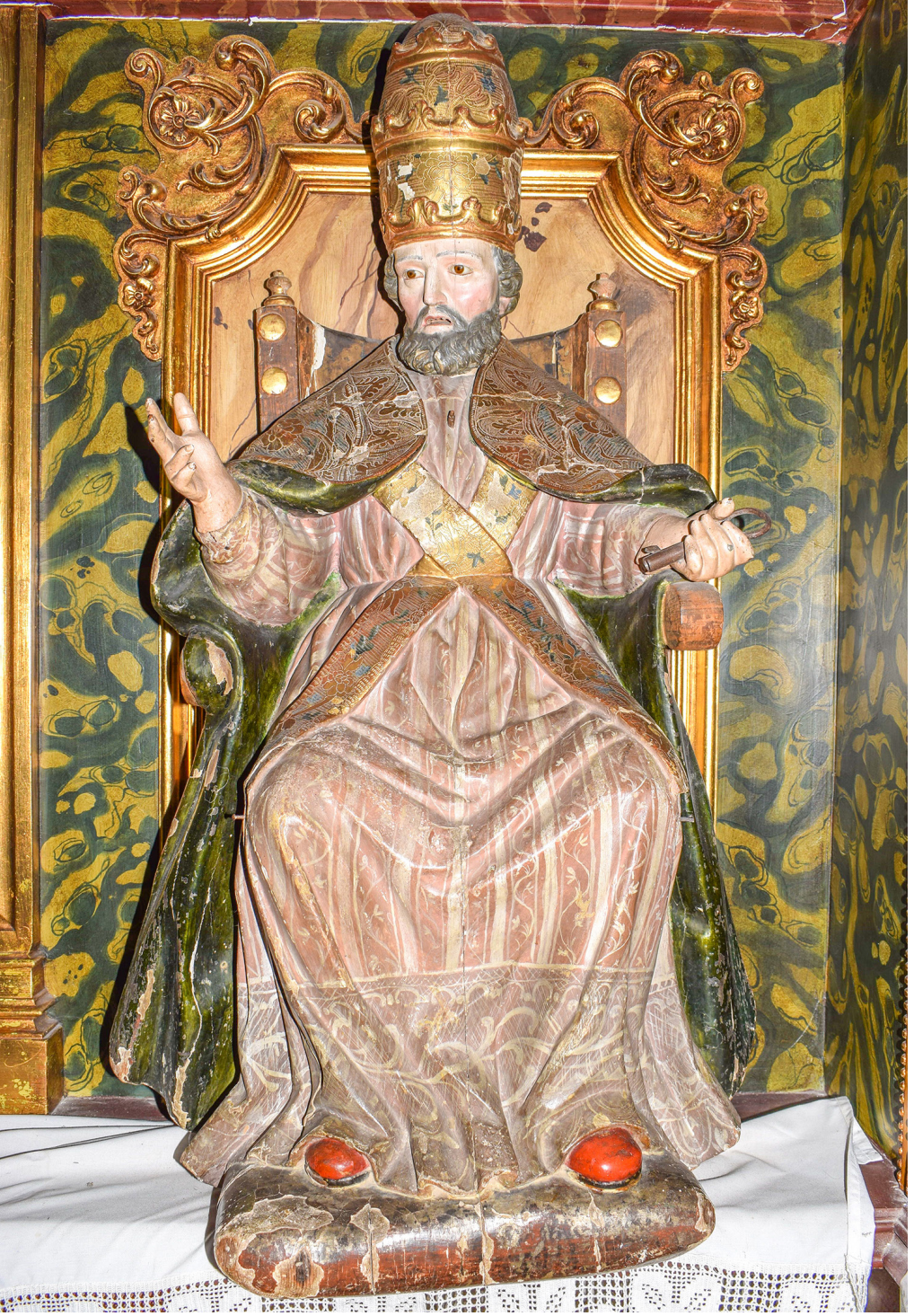

Fig. 8: San Pedro en cátedra. Felipe de Espinabete (atr.). 1789. Iglesia de la Asunción. La Pedraja de Portillo (Valladolid) 
mientras reposa los pies sobre una almohada. Aparece revestido de pontifical: alba blanca con franjas rojas e imitación de labores de brocado en la parte inferior, y capa pluvial que por la parte interior es verde y por la exterior está decorada con motivos vegetales ricamente dorados y puntillados. La cabeza va tocada por la tiara pontificia y las manos protegidas por guantes. Con la mano derecha imparte la bendición mientras que, con la otra, cuyo brazo mantiene sobre el reposabrazos, sujeta sus características dos llaves. A pesar de que la labra del cuerpo es correcta la figura adolece de dinamismo, siendo lo más sobresaliente la ejecución de la cabeza.

San Pedro es un anciano con pelo y barba canosa y con un semblante rebosante de naturalismo y espontaneidad ya que al tener la boca entreabierta parece encontrarse interactuando con el espectador. El parecido que posee el rostro con sus ejemplares de la Cabeza de San Pablo -en esta ocasión presenta una factura más simple y de menor detallismo y finura, quizás debido a la decadencia artística del escultor en sus últimos años-, además de la presencia de sus característicos ojos con el lacrimal recurvado, y las policromías doradas con decoraciones efectuadas en puntillado parecen apuntar a la autoría de Espinabete.

\subsection{Virgen de la Soledad (Último tercio del siglo XVIII). Iglesia de los Santos Juanes. Nava del Rey (Valladolid)}

Otra imagen que procede asignarle es una bellísima Virgen de la Soledad de vestir ${ }^{84}$ que se conserva junto a un potente Crucificado a los pies de la nave del Evangelio de la parroquial de Nava del Rey. Ambas imágenes ocupaban un altar decorado con pinturas murales

producido en el noroeste peninsular durante los siglos XVII y XVIII. Así, podemos citar el que Juan de Ávila esculpió en 1692 para el retablo mayor de la Colegiata de San Pedro de Lerma, o los anónimos existentes en la parroquial de Zaratán y en la iglesia de San Pedro de Valladolid.

84 Se trataría de la segunda Virgen de la Soledad de vestir que se relaciona con Espinabete puesto que sabemos que hacia el año 1779 esculpió otra para la Cofradía de Nuestra Señora de la Soledad y Santo Entierro de Cristo de Toro (Zamora), la cual por desgracia pereció en 1957 víctima de un incendio. EAVARRO TAIEGóN J: Cotólo NAVARRO TALEGON, ,.. Catalogo..., op. cit., p. 163, CAMARON VALDERAS, J.: La Semana Santa en Toro. Cofradia del Dulce Nombre de Jesus Nazareno, Nuestr Señom de la Campanilla. Incendio de la iglesia de Santa María de Roncesvalles y Santa Catalina. 13 de abril de 1957, Cincuenta aniversario. Toro, 2007, p. 23. dieciochescas puesto bajo la advocación del Cristo de la Buena Muerte en el Hospital de San Miguel de la citada localidad, aunque parece ser que la Dolorosa llegó allí en 1897 tras cerrarse al culto el desaparecido oratorio de Carneruelo ${ }^{85}$.

Se trata de una escultura de vestir, pero también de bastidor puesto que tan solo tiene talladas las manos y la cabeza, que viene a ser una repercusión tardía de algunas imágenes marianas de Gregorio Fernández, especialmente la Virgen de la Vera Cruz y algunas Piedades. Extiende las manos a modo de súplica y va ataviada con una larga toca blanca, saya del mismo color y manto de terciopelo negro, vestimenta que portaban las viudas nobles de la época. Eleva la mirada hacia el cielo, suplicante, como solicitando respuesta por la cruel muerte de su Hijo. Posee un rostro muy bello a la par que trágico, dramatismo que se hace patente en la boca entreabierta, los ojos hinchados, de los cuales escapan algunas lágrimas, y las cejas fuertemente enarcadas. Se trata de un profundo dolor, a la par que sereno, contenido y resignado. Hay que reseñar la altísima calidad de su modelado, ya que ha labrado minuciosamente los rasgos faciales, algo lógico dado que la expresividad de las esculturas de vestir se concentra en la cabeza y en las manos. Nuevamente hemos de recurrir a su característica manera de resolver los ojos para cimentar la atribución.

\subsection{San Ramón Nonato (Último tercio del siglo XVIII). Iglesia de Santa} María. Tordesillas (Valladolid)

También le atribuimos la efigie de un santo, a buen seguro San Ramón Nonato (Fig. 9), localizada en el coro bajo de la iglesia de Santa María de Tordesillas, si bien desconocemos si perteneció a este templo o a otro edificio religioso de la localidad puesto que no aparece reseñada en ningún inventario o catálogo monumental. Creemos que se trata del referido santo debido a los ropajes que viste (larga túnica, sobrepelliz con una imitación de encaje en la parte inferior y una muceta roja) puesto que los atributos han desaparecido. En tal caso portaría una custodia en la mano derecha, cuya base parece que ase entre los dedos, y en la izquierda una palma del martirio con tres coronas que aludieran a sus virtudes.

85 CASTÁN LANASPA, J.: Catálogo Monumental de la provincia de Valladolid. Tomo XXI. Antiguo partido judicial de Nava del Rey. Valladolid, 2006, pp. 89 y 116. 


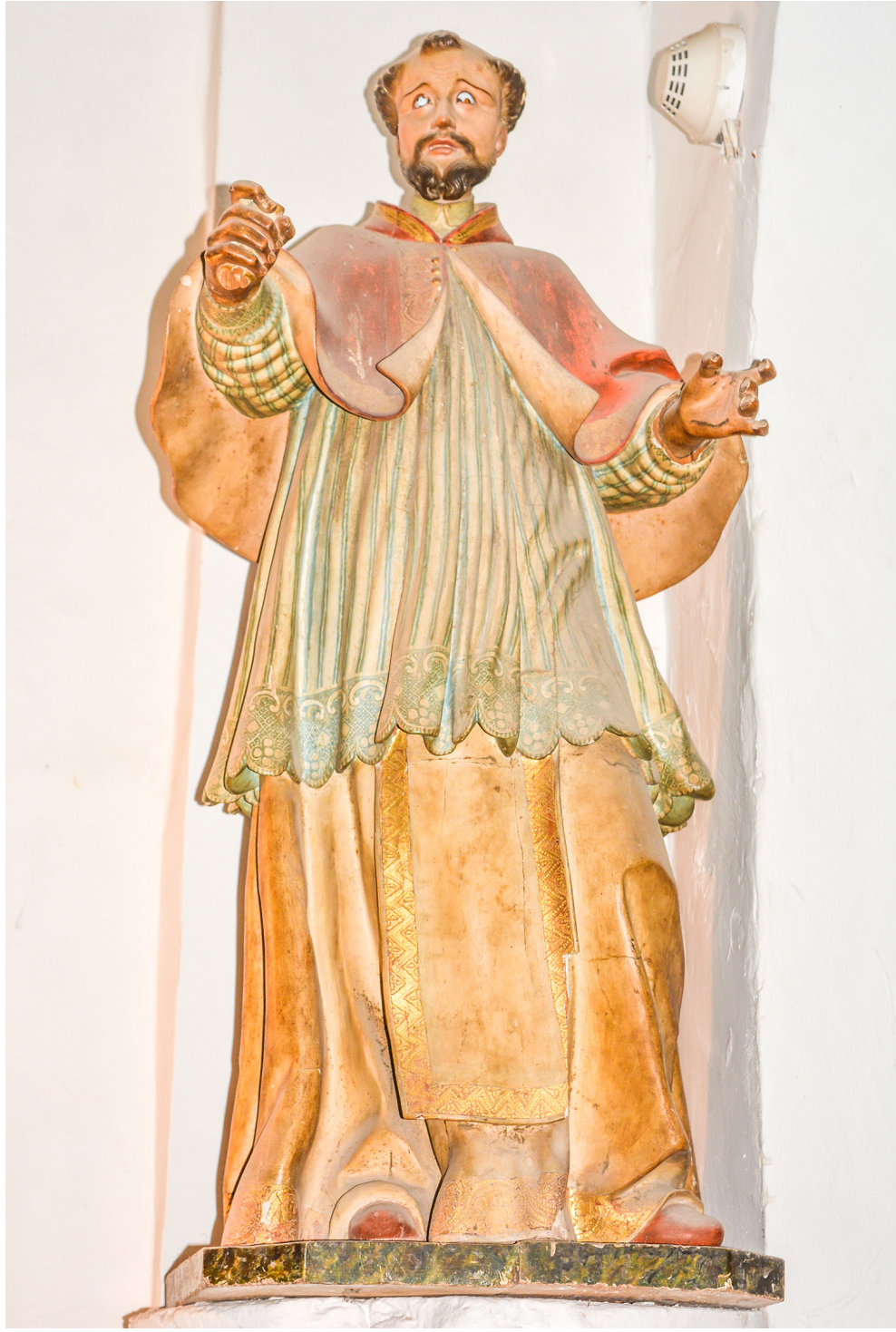

Fig. 9: San Ramón Nonato. Felipe de Espinabete (atr.). Último tercio del siglo XVIII. Iglesia d Santa María. Tordesillas (Valladolid)
Se trata de una imagen un tanto envarada que denota bastante labor de taller, con unos pliegues sumamente rígidos y acartonados. Lo más valioso es la cabeza, que muestra los característicos rasgos faciales del escultor, recordando sobremanera a la del San Juan Nepomuceno de la iglesia de la Magdalena de Valladolid, si bien baja bastante en calidad con respecto a aquel ${ }^{86}$. A pesar de la cantidad de polvo y suciedad se percibe una riquísima policromía característica en las esculturas de Espinabete como pueden ser las orlas o decoraciones doradas puntilladas.

\subsection{San Buenaventura. Iglesia de San Pedro. Tordesillas (Valladolid)}

También en su localidad natal, y más concretamente en el baptisterio de la iglesia de San Pedro, puede asignársele un San Buenaventura que quizás proceda del Convento de San Francisco ${ }^{87}$, cenobio para el que el escultor trabajó en diversas ocasiones. El santo va ataviado con hábito franciscano (túnica hasta los pies y sandalias), roquete, y muceta roja de cardenal. Tanto la túnica como el roquete van surcados por pliegues a cuchillo. En la mano izquierda porta un libro y en la derecha, cuyos dedos están fracturados, pudo hacer lo propio con una pluma, simbolizando así su faceta de escritor y labor evangelizadora. El rostro está concebido con gran blandura, representado a la perfección las arrugas y piel colgante de un personaje maduro como es este santo. Peina una amplia tonsura. A pesar de que los rasgos faciales son los característicos del escultor la labra no es tan delicada como en sus obras personales por lo que quizás haya que pensar en la participación del taller.

\subsection{San Martín partiendo la capa con un pobre. Iglesia de San Martín. Bernuy de Zapardiel (Ávila)}

Una obra menor dentro de su producción es el grupo de San Martín partiendo la capa con un pobre que le atribuimos en el retablo mayor de la parroquial de San Martín de Bernuy de Zapardiel, que resulta ser un remedo del que tenemos documentado que esculpió en 1753 para la iglesia de San Martín de Arévalo ${ }^{88}$. San Martín de Tours o San Martín obispo (316-

86 BALADRÓN ALONSO, J.: “El escultor...”, op. cit., pp. 215-217.

87 El catálogo monumental señala que a los pies de la iglesia conventual se hallaban dos esculturas de santos franciscanos $(95 \mathrm{~cm}$ y $102 \mathrm{~cm}$ ), una de las cuales bien puede ser la que nos ocupa. ARA GIL, C J. y PARRADO DEL OLMO, J. M.: op. cit., p. 298.

88 VÁZQUEZ GARCÍA, F.: "Varias esculturas..., op. cit., p. 445-447. También resulta harto similar el reta- 
397) fue el Apóstol de Las Galias y obispo de Tours, aunque previamente había ejercido de soldado del ejército romano. El grupo representa su milagro más conocido, aquel que relata que en el invierno de 337 encontrándose en una guarnición cerca de la puerta de la ciudad de Amiens (Francia) se le acercó un mendigo que solicitó auxilio para combatir el frío. Martín conmovido no dudó en ayudarle y para ello partió su capa para compartirla y darle abrigo. Así, San Martín monta un caballo blanco que marcha al paso y que levanta la pata delantera izquierda. El jinete, que posa sus pies sobre los estribos, vuelve su cuerpo hacia el mismo lado para que el espectador pueda observar cómo se dispone a partir con la espada su capa, con la que desea auxiliar al pobre. Aparece efigiado como un joven militar que viste lujosas vestimentas a lo que suma unas largas botas, coraza con amplio escote y ricamente decorada con motivos florales, y un curioso casco con penachos. A su derecha se encuentra el pobre, que eleva el brazo derecho para recibir el presente con el que se protegerá del frío. Se acerca al jinete llevando apoyado el brazo izquierdo sobre una muleta lo que nos indica que está tullido. Se trata de un hombre de media edad, barbado y que viste ropas bastante cortas que dejan a la vista buena parte de su cuerpo, especialmente las piernas y parte del torso, lo que nos indica un interés por el desnudo por parte del escultor. Resulta curioso el contraste entre la efigie idealizada del santo y la profundamente naturalista del pobre, no exenta de una gran dignidad, y que además resulta ser la más valiosa de las dos. Los motivos para la atribución a Espinabete son, además del cercano parentesco con el ejemplar de Arévalo, como ya hemos referido, la aparición de sus clásicos estilemas en el rostro y en la barba. La modesta calidad de la pieza será indicativa de que Espinabete delegó la ejecución en su taller

2.11. San Antonio de Padua (Último tercio del siglo XVIII). Convento del Domus Dei. La Aguilera (Burgos)

Otra obra de gran calidad, y que tampoco presenta dudas para su adscripción a nuestro escultor, es un San Antonio de Padua (Fig. 10) conservado en el tránsito hacia la capilla de San Pedro Regalado del Convento del Domus Dei de La Aguilera. El hecho de que

blo al de la iglesia de San Martín de Arévalo, de suerte que su autor pudo ser también Felipe de la Cruz cinas laterales tien cabida una escultura reaprovechada de San Ramón Nonato y un santo dominico ¿San Vicente Ferrer? posiblemente obra realizada ex profeso para el retablo por algún miembro de la familia Sierra, quizá José o Pedro pues sabemos que trabajaron por la zona.

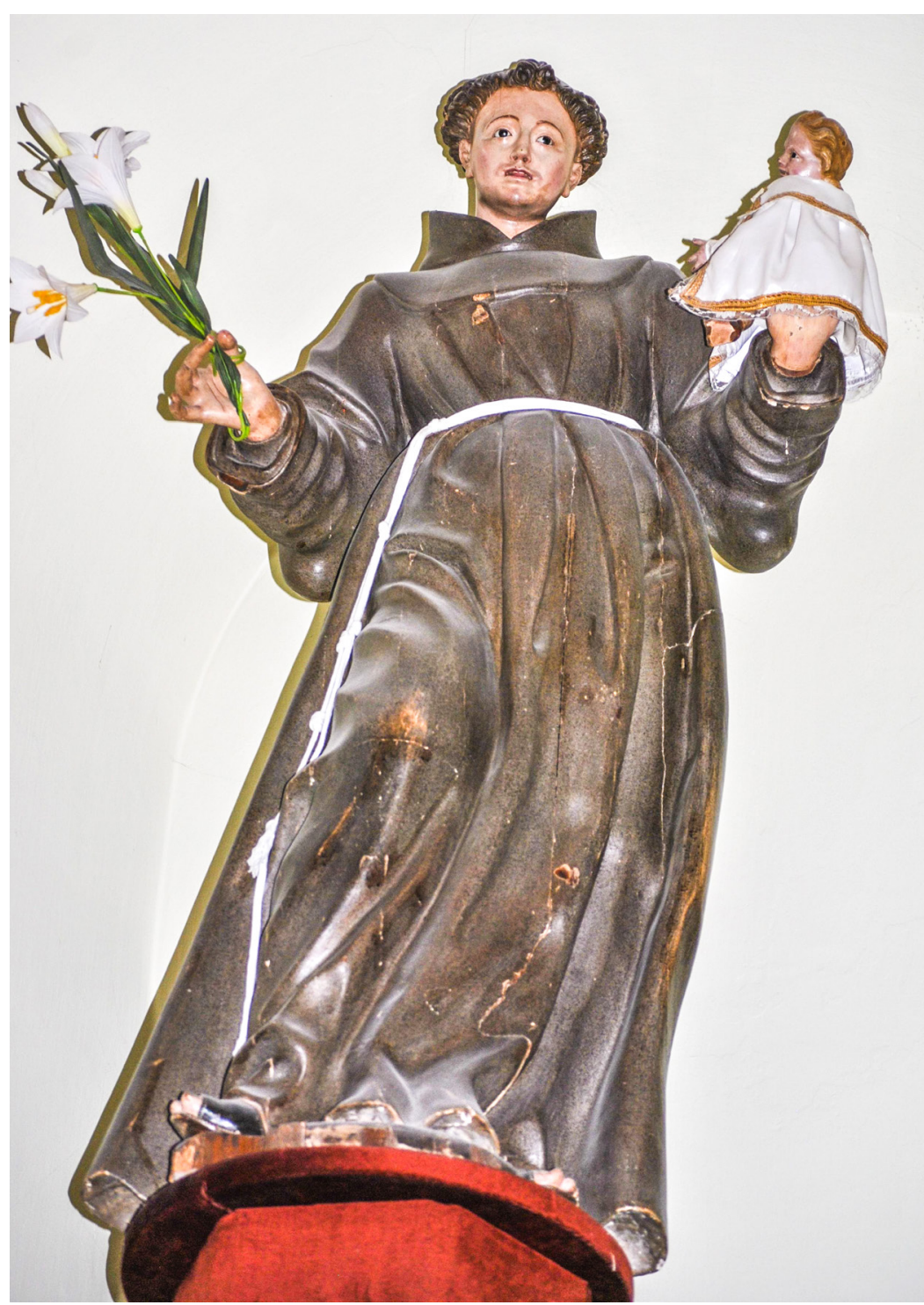

Fig. 10: San Antonio de Padua. Felipe de Espinabete (atr.). Último tercio del siglo XVIII. Convento de Domus Dei. La Aguilera (Burgos) 
esta orden en otras ocasiones, además de que era vecino del Convento de San Francisco de Valladolid, parece reforzar esta asignación. San Antonio, que combina un porte monumental con una elegancia y una gracia plenamente dieciochesca, figura según el característico ademán del escultor de pie, realizando un contrapposto con la pierna derecha, cuya rodilla se intuye bajo la túnica. Viste hábito franciscano compuesto por larga túnica cuajada de pliegues serpenteantes y sandalias. En la mano izquierda porta un Niño Jesús de vestir mientras que en la derecha exhibe un ramo de lirios, atributo que alude a su pureza. Las manos son muy expresivas y delicadas, como también lo es la magnífica cabeza (el rostro y su expresión emparentan con los del San Serapio), que exhibe una blandura que la hacen sin duda obra personal del escultor. Mantiene la boca entreabierta, de suerte que se le aprecien los dientes y la punta de la lengua, y peina una abultada cabellera con un gran copete de rizos sobre la frente.

\section{CONCLUSIONES}

La extenta distribución geográfica que presentan las obras que le acabamos de atribuir así como el elevado número de ellas y la existencia de una desigual factura en las mismas son elementos indicativos de que Espinabete regentó un amplio taller capaz de satisfacer la numerosa demanda recibida, lo que a su vez confirmaría la supremacía artística de la que gozó entre los talleres escultóricos vallisoletanos de la segunda mitad del siglo XVIII. Las diferencias de calidad visibles de unas obras a otras estarán relacionadas con el sueldo percibido o la importancia del comitente. Así, Espinabete se encargaría de forma personal de las que le reportaban mayor retribución o estaban destinadas a una persona o institución relevante, mientras que en el resto delegaría en sus oficiales y aprendices.

Sus comitentes fueron muy variados: desde el patronago privado a iglesias de todo tipo (parroquias tanto rurales como de Valladolid capital), pasando por cofradías y órdenes monásticas, teniendo un gran peso dentro de éstas la benedictina y, sobre todo, la franciscana. Finalmente, a través de Espinabete se puede ir siguiendo la transformación sufrida por la escultura vallisoletana a lo largo de casi medio siglo en el que transitará desde el Barroco al Neoclasicismo, pasando por el Rococó, que será el periodo en el que produzca la mayor parte de su obra, y creemos que también fue en el que se encontró más cómodo debido a su gusto por las figuras gráciles. A pesar de esta evolución sus principales rasgos estilísticos se mantuvieron casi inmutables desde el principio, modificándose tan solo el tipo de paño y el mayor o menor atemperamiento de las actitudes de los personajes salidos de sus gubias. 


\section{BIBLIOGRAFÍA}

AGAPITO Y REVILlA, J.: Catálogos del Museo de Bellas Artes de Valladolid. I, Escultura. Valladolid, 1930

ALBARRÁN MARTÍN, V.: "Un San Francisco del escultor Felipe de Espinabete (17191799)", B.R.A.C., No 45, 2010, pp. 65-68.

ALBARRÁN MARTÍN, V.: El escultor Alejandro Carnicero entre Valladolid y la Corte (1693-1756). Valladolid, 2012.

ALEGRE PASTOR, P.: La historia de Valdunquillo y la Orden de la Merced Descalza. Salamanca, 2005

ALONSO AGUADO, M.: "San Serapio, mártir. A pequeña escala", Caminos de liberación, No 178, Año 37, 2016, pp. 8-9.

ARA GIL, C. J. y PARRADO DEL OLMO, J. M.: Catálogo Monumental de la provincia de Valladolid. Tomo XI. Antiguo partido judicial de Tordesillas. Valladolid, 1980.

ARIAS MARTÍNEZ, M., HERNÁNDEZ REDONDO, J. I. y SÁNCHEZ DEL BARRIO, A. Clausuras: el patrimonio de los conventos de la provincia de Valladolid. 1, Medina del Campo. Valladolid, 1999.

ARRANZ SANTOS, C. y FRAILE DE PABLO, A.: Historia de Vallelado, tierra de Cuéllar. Valladolid, 1998.

BALADRÓN ALONSO, J.: "El escultor Felipe de Espinabete. Nuevas atribuciones e hipótesis sobre su posible formación”, BSAA Arte, No 82, 2016, pp. 205-227.

BALADRÓN ALONSO, J.: "Nuevas obras de Francisco Díez de Tudanca y otros datos de escultores barrocos vallisoletanos", BSAA Arte, No 78, 2012, pp. 153-170.

BALADRÓN ALONSO, J.: Los Ávila. Una familia de escultores barrocos vallisoletanos [Tesis doctoral inédita]. Valladolid, 2006.
BRASAS EGIDO, J. C. y NIETO GONZÁLEZ, J. R.: "Felipe de Espinabete: nuevas obras", B.S.A.A., No 43, 1977, pp. 479-484.

BRASAS EGIDO, J. C.: “Noticias sobre Espinabete”, B.S.A.A., No 45, 1979, pp. 495-498.

BRASAS EGIDO, J. C.: Catálogo Monumental de la provincia de Valladolid. Tomo X. Antiguo partido judicial de Olmedo. Valladolid, 1977.

CAAMAÑO MARTÍNEZ, J. M.: "Datos para la historia de la Real Academia de la Purísima Concepción, de Valladolid (1786-1797)”, Boletín del Seminario de Arte y Arqueología (en adelante B.S.A.A.), № 29, 1963, pp. 89-151.

CAMARÓN VALDERAS, J.: La Semana Santa en Toro. Cofradía del Dulce Nombre de Jesús Nazareno, Nuestra Señora de las Angustias Soledad, y Ánimas de la Campanilla. Incendio de la iglesia de Santa María de Roncesvalles y Santa Catalina. 13 de abril de 1957, Cincuenta aniversario. Toro, 2007.

HERRÁEZ ORTEGA, M. V. [et al.]: Esplendor y decadencia de un monasterio medieval: el patrimonio artístico de San Benito de Sahagún, León, 2000.

CANESI ACEVEDO, M.: Historia de Valladolid (1750). Valladolid, 1996.

CASTÁN LANASPA, J.: Catálogo Monumental de la provincia de Valladolid. Tomo XXI. Antiguo partido judicial de Nava del Rey. Valladolid, 2006.

FERNÁNDEZ GONZÁLEZ, M. R.: "La sillería del coro alto del monasterio de San Benito el Real, de Valladolid”, B.S.A.A., № 60, 1994, pp. 499-514.

FRUTOS SASTRE, L. M.: "Dos nuevos pasos procesionales de Felipe de Espinabete en la provincia de Segovia". Boletín de la Real Academia de Bellas Artes de la Purísima Concepción (en adelante B.R.A.C.), No 37, 2002, pp. 107-112.

GARCÍA CHICO, E.: Documentos para el estudio del arte en Castilla. 2, Escultores. Valladolid, 1941.

GARCÍA MARTÍN, E.: “Las cofradías de Tordesillas en el siglo XVIII”. En REDONDO, J., BAZÁN, P. y GARCÍA, A. M.: Tordesillas a través de su Semana Santa. Valladolid, 2000, p. 33. 
GONZÁLEZ GARCÍA-VALLADOLID, C.: Valladolid, sus recuerdos y sus grandezas: religión, historia, ciencias, literatura, industria, comercio y política. Valladolid, 1900.

MARTÍ Y MONSÓ, J.: Estudios histórico-artísticos relativos principalmente a Valladolid: basados en la investigación de diversos archivos. Valladolid, 1898-1901.

MARTÍN GONZÁLEZ, J. J. (dir.): Inventario artístico de Valladolid y su provincia. Valladolid, 1970.

MARTÍN GONZÁLEZ, J. J. y DE LA PLAZA SANTIAGO, F. J.: Catálogo Monumental de la provincia de Valladolid. Tomo XV. Monumentos religiosos de la ciudad de Valladolid ( $2^{a}$ parte). Valladolid, 2001

ARIAS MARTÍNEZ, M., HERNÁNDEZ REDONDO, J. I. y SÁNCHEZ DEL BARRIO, A. Clausuras: el patrimonio de los conventos de la provincia de Valladolid. 3, Medina de Rioseco - Mayorga de Campos - Tordesillas - Fuensaldaña y Villafrechós. Valladolid, 2004

MARTÍN GONZÁLEZ, J. J. y URREA FERNÁNDEZ, J.: Catálogo Monumental de la provincia de Valladolid. Tomo XIV. Monumentos religiosos de la ciudad de Valladolid ( $1^{a}$ parte). Valladolid, 1985.

MARTÍN GONZÁLEZ, J. J.: "Cabezas de santos degollados en la escultura barroca española”, Goya: revista de arte, № 16, 1957, pp. 210-213.

MARTÍN GONZÁLEZ, J. J.: Escultura barroca castellana. Madrid, 1959.

MARTÍN GONZÁLEZ, J. J.: Escultura barroca en España, 1600-1770. Madrid, 1991.

MARTÍN GONZÁLEZ, J.J.: Escultura barroca castellana. Segunda parte. Madrid, 1971.

NAVARRO TALEGÓN, J.: Catálogo monumental de Toro y su Alfoz. Zamora, 1980.

NAVARRO TALEGÓN, J.: I centenario de la fundación de la Orden Mercedaria descalza de Toro (1886-1986). Zamora, 1986

REDONDO CANTERA, M. J.: "Los inventarios de obras de arte de los conventos vallisoletanos durante la Guerra de la Independencia”, B.S.A.A., No 58, 1992, pp. 497-510.
RIVERA DE LAS HERAS, J. A.: "Santa María Magdalena Penitente”. En VV.AA.: Las Edades del Hombre. El árbol de la vida. Salamanca, 2003, pp. 404-405.

RODRÍGUEZ MARTÍNEZ, L.: Historia del Monasterio de San Benito el Real de Valladolid. Valladolid, 1971.

URREA FERNÁNDEZ, J.: Cuadernos vallisoletanos No 24: Semana Santa. Valladolid, 1987.

URREA, J. (coord.). El Museo de Santa María de Medina de Rioseco. Valladolid, 1987.

URREA, J. y BRASAS EGIDO, J. C.: Catálogo Monumental de la provincia de Valladolid. Tomo XII. Antiguo partido judicial de Villalón. Valladolid, 1981.

URREA, J.: “El escultor Felipe de Espinabete (1719-1799)”. En REDONDO, J.; BAZÁN, P.; GARCÍA, A. M.: Tordesillas a través de su Semana Santa. Valladolid, 2000, pp. 119-122.

URREA, J.: "Nuevos datos y obras del escultor Felipe de Espinabete", B.S.A.A., No 51, 1985 pp. 507-510.

VALDIVIESO, E.: Catálogo Monumental de la provincia de Valladolid. Tomo VIII. Antiguo partido judicial de Peñafiel. Valladolid, 1975.

VÁZQUEZ GARCÍA, F.: "Esculturas de Felipe de Espinabete en San Martín de Arévalo". Cuadernos de Cultura y Patrimonio. La Alhóndiga, Asociación de Cultura y Patrimonio, No $22,2013, \mathrm{~s} / \mathrm{p}$.

VÁZQUEZ GARCÍA, F.: "Varias esculturas de Felipe de Espinabete en iglesias abulenses", B.S.A.A., No 57, 1991, pp. 445-452.

VELASCO GALLEGO, S.: "San Antonio Abad". En VV.AA.: Las Edades del Hombre. Monacatus. San Bernardo (Valladolid), 2012, p. 200.

WATTENBERG, F: Guía del Museo Nacional de Escultura de Valladolid. Madrid, 1966.

YARZA LUACES, J.: "Un San Juan Bautista degollado de Felipe de Espinabete en Santibáñez del Val (Burgos)", B.S.A.A., No 38, 1972, pp. 560-562. 